University of Louisville

ThinkIR: The University of Louisville's Institutional Repository

Electronic Theses and Dissertations

1943

\title{
A history of the Kentucky School for the Blind, 1842-1930.
}

Gretchen R. Wright

University of Louisville

Follow this and additional works at: https://ir.library.louisville.edu/etd

Part of the History Commons

\section{Recommended Citation}

Wright, Gretchen R., "A history of the Kentucky School for the Blind, 1842-1930." (1943). Electronic Theses and Dissertations. Paper 2191.

https://doi.org/10.18297/etd/2191

This Master's Thesis is brought to you for free and open access by ThinkIR: The University of Louisville's Institutional Repository. It has been accepted for inclusion in Electronic Theses and Dissertations by an authorized administrator of ThinkIR: The University of Louisville's Institutional Repository. This title appears here courtesy of the author, who has retained all other copyrights. For more information, please contact thinkir@louisville.edu. 
UNIVERSITY OF LOUISVILLE

\begin{abstract}
A HISTORY OP THE KBNTUCKY SCHOOL FOR THE BLIND,
\end{abstract}

$$
1842-1930
$$

\author{
A Dissertation \\ Submitted to the Faculty \\ Of the Graduate School of the University of Louisville \\ In Partial Fulfillment of the \\ Requirements for the Degree \\ Of Master of Arts
}

Department of History

By

Grotohen R. Wright

Year

1943 
This PDF document is a scanned copy of a paper manuscript housed in the University of Louisville (UofL) Libraries. The quality of this reproduction is greatly dependent upon the condition of the original paper copy. Indistinct print and poor quality illustrations are a direct reflection of the quality of materials that are available for scanning. The UofL Libraries greatly appreciates any better copies that can be made available for replacement scans. 
NAME OF STUDENT: Gretchen R. Wright

TITLE OF THESIS: A History of the Kentucky Sohool For The Blind, $1842=1930$

APPROVED BY READING COMMTTEE COMPOSED OF THE FOLLOWING MEMBERS :

W. C. Mallalieu

$\begin{array}{r}\text { Robert Warner } \\ \hline \text { John J. Cronin } \\ \hline\end{array}$

NAME OF DIRBCTOR: W. C. Mallalieu

DATE: 1943 
I herewith acknowledge with gratitude and appreoiation the assistance given me by the following persons and organizations in the preparation of this thesis: to Dr. W. C. Mallalieu for his very helpful guidence in directing my writing of this history; to the Louisville Free Public Library, the University of Louisville Library, the Cincinnati Public Library, the Louisville Law Library, the Filson Historical Library, the Jefferson County Court House, the American Printing House for the Blind, the Kentucky Historical Society, the Kentuoky State Library at Frankfort, the American Foundation for the Blind, the Perkins Institute and Mssachusetts School for the Blind, and the State Board of Eduoation for making arailable to me their records and other valuable materials used in oompiling the information which constitutes much of this history; to Mr. and Mrs. Clifford B. Martin, Mr. Harold Reagan, and Superintendent A. C. EIlis of the American Frinting House for the Blind for their generosity in granting me interviews; to Dr. R. A. Warner and Dr. John J. Cronin for reading this thesis in its final form. 
TABLE OF CONTENTS

Page

ACKNOWLEDGEMENTS . . . . . . . . . . . . . . i

Chapter I - Education of the Blind Prior to 1842 . . . I

Chapter II - Formative Years, 1842 - 1844 . . . . . 16

Chapter III - Decade of Progress, 1845 - 1855 . . . 29

Chapter IV - Years of Expansion, 1855 - 1930 ... . 45

Chapter V - American Printing House For The Blind, 1856 - 1942 ............ 65

Chapter VI - Conclusion . . . . . . . . . 73

APPENDIX . . . . . . . . . . . . . 75

An Act To Establish The Kentuoky Institution

For The Eduation of the Blind. . . . . 75

Nembers of the Board of Visitors . . . . 77

Number of Students Enrolled Each Year in

Kentuoky School For The Blind . . . . . 80

BIBLIOGRAPHY .................. 81 
CHAPTER I

EDUCATION OF THE BLIND PRIOR TO 1842 


\section{CHAPTER I}

"The condition of the blind is, at best, a most pitiable one, and one that the benevolent orery where are disposed to commiserate, and, if possible to alleviate."l Throughout the ages, "from Homer to Helen Keller," the blind have evoked much pity, compassion and charity. Today, through a broad program of oducation, these handicapped people are not seeking commiseration for their great misfortune, but are learning to utilize their remaining senses to the utmost in order to adjust and fit themselves into present-day society. But how and when did this most worthy program of education come about? In order to answer this question, it will be necessary to trace briefly the various trends of thought ooncerning the condition and lot of the blind throughout history. Among anoient peoples, including the Greeks, each newborn child was carefully examined to determine if it was physically ilt for citizenship. If the infant was found to be imperfeot, it was to be disposed of, generally by exposure in the mountains or left to die in the wilderness. A child blind from birth was subjeot to the same practice of exposure as any other afflicted offspring. Among the Egyptians and the Jews, however, parental disposal of unwanted children was forbidden. The Jews belleved that the ohild was a gift of the Lord and belonged to Him. However, these ohildren could be sold into slavery to anyone who would pay a small price, and the child became the sleve of the one who raised him. 2 If by chance, the blind ohild did grow up, ho had little

1. Report of the Kentucky Institution for the Blind, 1848, p. 11

2. Richard Slaton French, From Homer to Helen Keller, American Foundation For The Blind, Hew York, 1932, p. 33 
opportunity of being eared for. The blind were an economic liability and no one knew what to do with them. As a consequence, the role of the blind became that of the beggar. "In Rome, for example, blind boys were trained to become beggars or sold as rowers and girls were made prostitutes." ${ }^{1}$ Among some of the ancient, and even more modern, peoples, the affliotions of the blind were oonsidered a divine visitation, "and in divers forms was the question askod, 'Who did sin, this man, or his parents? " ${ }^{2}$

In Chine and India, the blind were carly amployed in a fow gainful and useful ocoupations, for example, that of soothsayer in China and that of "transmitter of oral tradition" in India, "some blind boing veritable walking libraries." ${ }^{3}$ The blind were also used to serve as "guides across deserts, and in leading peoplo through the streets of cities in times of darkness and heavy fog." 4

Howerer, it is not until after the advent of the Christian era that any marked ohange appears in the general attitude toward the blind. The ohuroh early showed a direct concern for these unfortunates, gave them charity, and welcomed them at the hospitals and monasteries. In the fourth century St. Basil established a hospice for the blind at Caesarea in Cappadocia. The following century, a refuge was offered to the blind by the hermit St. Lymmaeus at Syr in Syria. About the middle of the seventh century, a typhlocomium, or retreat, was set up for the benefit of the sightless in Jerusalem. Similar institutions

1. Ibid.. p. 34

2. Harry Best, Blindness and the Blind in the United States, Hacmillan Company, New York, 1934, p. 299

3. Frenoh, 오. o1t., p. 299

4. Bost, 오. eit., 299 
were set up in Franoe, Italy, and Germany. It is said that William the Conqueror, during the eleventh century, founded among other institutions hospices for the blind and other infirm persons at Cherbourg, Rouen, Bayoux, and Caen, "in expiation for his sins,"l

The first publio effort to benefit the blind was the founding of a hospital at Paris in 1254, by Louis IX, or St. Louis, known as the "Hotel des Quinse-Vingts," or "Congrogation and House of the Three Hundred." The tradition is that this asylum was created to care for some three hundred orusaders who had returned to Western Europe with their sight destroyed, either as a result of diseases contracted on their journeys, or by the order of the Turkish Sultan, who blinded twenty crusaders each day whilo awaiting ransom money for Louis IX. ${ }^{2}$ Later other persons we admitted to the hospioe, Irrespective of the origin of their blindness. "For the support of this home, begging was encouraged on the part of the inmates, direot gifts also coming to it from the charitably inolined. "3 During the years that ensued, the "Quinze-Vingts" came into great prominence, was accorded many privileges by the Frenoh kings and high soolety, and still exists in Paris today, "though under greatly ohanged oonditions. "4 While other "hospital brotherhoods" sprang up in Franoe during the Middle Ages, a movement known as "free brotherhoods" was started in Italy, Spain, and Germany. "The ain of such organizations was reciprocal aid and improvement among the members and included a sooial obligation for the care of the poor. Elech brotherhood was connected with some

1. Ibid., p: 300

2. Froneh, op. oit., PP. 46-47

3. Best, op. oit., p. 300

4. French, op- cit., p. 49 
speoified church and was under the patronage of saint. The rights and duties of the members were set by statute. The organizations of the blind were not nocessarily confined to those of like fate but might inolude other defectives, more particularly the orippled and lame." 1

Throughout the oenturies, and continuing well into the Middle Ages, the responsibility for ameliorating the condition of the handicapped was left to religious charitable organizations. Howerer, this charity reached only a very small portion of the sightless, for, whil. many were cared for in the hospioes and cloisters, a still larger number were forced to eke out an existenee of beggary, often struggling for positions farorable for asking alms. ${ }^{2}$

During all this period very little, if any, attempt was made to give instruction to the blind. It is not until the sixteenth century, the period of the revival of learning, that the first efforts were made to bring to the blind "light out of darkness." Girolimo Cardano, a physioian of Pavia, Italy, haring become interested in the deaf and their education, conceived the 1dea that through the sense of touch, the blind might bo given an oduoation, and he attempted to some extent to procure instruotion for them. ${ }^{3}$ In his book, From Homer to Helen Keller, Riohard French states that the most famous case of the oducation of a blind person up to the close of the eighteenth oentury was that of the blind mathematician, Mioholas Saunderson, sometime professor at Cambridge. Saundorson plays an important part in the history

1. Ibld., p. 49

2. S1r Franois J. Canpoll, "Blindness," Fnoyclopedia Britannioa, Eleventh Edition, Volume IV, New York, 1910, p. 61

3. Best, op. olt., p. 301 
of meohanical devioes for the blind. ${ }^{l}$ Another pioneer in the field of education for the blind was Blind Jacob of Netra, a village of Hesse in Germany. Jaoob, who lived about the middle of the eighteenth century, was not born blind, but lost his sight at an early age. To him is credited the invention of a means of written communivation and record for the blind. "This he did by means of a system of notohes out with his lonife in small stioks similar to the system of 'tallies' kept by primitive and unoultured people. $n^{2}$

There is a popular, though sometimes mistaken, belief that the blind are particularly gifted in musio. Often a great deal of time and offort is spent on trying to make a musioian of a blind person possessing relatively little musical talent. However, even before the inoeption of the first sohool for the blind, there were cases of very suocessful music education. One of the most noted of these was Maria Therosia von Paradis, born in Vienno in 1759. At the age of three she lost her sight. Her parents discovered that she possessed a great love for musio and had a natural aptitude for learning. With skillful instruction, Maria developed her musical talents so that she became an acoomplished musielan, playing in the oourt churoh and before the Empress Maria Theresia. While in Paris on a European tour, this talented blind woman met Valentin Hauy, the man with whom the real work in education for the blind oommenced. 3

Valentin Hauy lived in Paris, France, during the latter half of the eighteenth century, and his attention was attracted to the blind

1. Page 67

2. French, op. eit., pp. 69-70

3. Ibld., p. 70 
beoause of the degrading abuses to which they were subjeoted. These poor unfortunates were often used as apeotacles of amusement for the public. On one oocasion, in 1771, Hauy witnessed a fair of St. Ovid, in Paris, in which an innkeoper had a group of blind men "attired in a ridioulous manner, decorated with peacook tails, asses' ears, and pasteboard spectaoles without glasses, in which oondition they gave a burlesque conoert for the profit of their employer."I Mored to pity by the sights whioh he saw day after day, Hauy determined to devote the remeinder of his life to the education of the blind, and attempt to improve thoir condition. "I shall substitute truth for this mookery," he said to himself. "I shall teach the blind to read and to write, and give them books printed by themselves. They shall be enabled to execute harmonious musio. $n^{2}$

Firm in his determination, Hauy colleoted all the information he could concerning the blind, and in 1784 began teaching a blind boy, Franoois Lesueur, whom he found begging in the streets and at churoh doors. Hauy offered to compensate the lad if he would beoome the subjeot of his educational experiments and Lesueur readily consented. Making great progress and taking much interest in his studies, Lesueur was soon ready for exhibition before the learned societies of Paris. Through these exhibitions, Hauy secured the interest of a few influential men, as well as the interest and substantial ald of government officials. In order that he might continue his oducational experiments, the Societe Philanthropique turned over to Hauy twelve blind ohildren for whom they had been caring. Thus, from this simple beginning, was formed the first class for the oducation of the blind,

1. Sir Francis J. Campbell, op. oit., p. 61

2. Ibid.. P. 61 Joseph M. Stadelman, "Hauy," The Catholio Bnoyolopedia, Vol. VII, p. 152 
which subsequently developed into the first sohool for the instruction and training of the sightless. To it was given the name of "L'Institution Nationale des Jeunes Areugles."

In 1791, after the outbreak of the Frenoh Revolution, the chool was taken over by the state, and remained thereafter a state institution. For some years after the Revolution, however, Heuy continued to support the school at his own expense. In 1801, whon it was Incorporated with the Hotel des Quinze-Vingts, Hauy resigned and opened a private sohool of his own, "Le Musee des Areugles."

In 1806 the Bperor Paul of Russia invited Hauy to Russia to establish there a sohool for the blind, which he did so suceessfully that others were oponed in Finland, Poland, and Sweden. 2 In 1791 the Sohool for the Indigent Blind was opened in Liverpool, "the objeot of which was to teach poor blind children to work at trades, to sing in church, and to play the organ." 3 In 1793, the Royal Blind Asylum and School was founded in Bdinburgh by Mr. David Miller, a blind man, and Reverend Dr. Darid Johnston. Comenting on the British relief for the blind, Dr. David G. Yates and Mr. Miohael Anagnos, in their artielo on "Education of the Blind" in the International Enoyclopedia, say: "The organized efforts made in Great Britain for the relief of the blind were founded upon the idea that as a class the blind must neoessarily remain at the foot of the social soale, forever dependent upon the more fortunate classes. Hence most of the British schools have never taken

1. Best, op. eit., p. 303

2. Best, "BIindnoss," Encyclopedia Britannice, 1943 Edition, Vol. III, p. 727

3. Page 392

4. Hichael Anagnos was the son-in-law of Dr. Samuel Howe, founder of Perkins Institute, first blind sohool in the United States. Mr. Anagnos succeeded Dr. Howe as superintendent of the sohool. 
a high stand in their literary or masioal training."

To Valentin Hauy is attributed the invention of embossed printing for the use of the blind. This invention was discoverod quite by aooident. Wille preparing instructive material with which to teach his first pupil, Francois Lesueur, Hauy notioed that in ordinary printing the wet sheet coming from the press showed the letters, on the opposite side of the sheet from the print, reversed and in slight relief. Lesueur showed this to Hauy and was able, through the sense of touch, to decipher some of the letters. Hauy then had type cast so as to show the relief print in the same order as the common print. The letters were slightly enlarged and the characters resembled the italic in form. In testing his pupils on this new print, ho discovered that eleven out of the fourteen were able to learn to read by the new method. Thus, by accident, was discovered the embossed method of printing used in blind sohools throughout the world for many years. 1 Hau's institution for the education of the blind in Paris was visited by persons interested in philenthropy from every country in the world. Among those who visited the school in the early years of the nineteenth century was a young student of medicine, John D. Fisher of Boston, Massachusetts. He became so interested and sympathotic with the movement, that he conceived the plan of starting a similar institution in New England upon his return to this oountry in 1826 . He began his work very quietly at first, broaching his plans to frionds, who quiokly formed a nuelous of enthusiastio workers. In 1829, as a result of their unceasing and untiring efforts, the Institution for the Blind

1. Frenoh, op. 어., p. 83 
of Now Bngland, the first institution of its kind in the United States, was incorporated, renamed soon thereafter the "Porkins Institute," in honor of Colonel Thomas H. Perkins, who donated his mansion and grounds on Pearl stroet, Boston, for this philanthropic enterprise. ${ }^{1}$

The move to establish the first blind sohool in the United States doubtless recoived much impotus from the trend of social and political thought which had developed in the early decades of the nineteenth century. It was an age of wide-spread movements to extend political and social demooracy among the fast inoreasing populace. Efforts were made to reoognize the common man, to extend manhood suffrage, to secure the rights of women and to enforce temperanee, to develop the abolition movement, and to open the doors of free eduoation to all persons alike, irrespective of their social standing. It was during this period that the common-school system was born, that the movement to establish acodemies and oolleges throughout the country was begun. Coincident with the revival of this intense interest in the development of publio edueation, there arose anong the philanthropic-minded a keen desire to better the condition of the physioally and mentally handioapped. Hospitals and asylums for the insane were established. Schools for the deaf and mute were dereloped and with the establishment of Perkins Institute, the movement for aiding and educating the blind was born.

Dr. Sarmel Gridley Howe was the real organizer of the sohool, which was not open to pupils until 1832. Dr. Howe was appointed to take full oherge of the institution, conduct its operations, and secure pupils for it. In order to prepare himself for the great task ahead,

1. Ibid., pp. 110-112; Best, op. it.. pp. 307-308 
Dr. Howe toured most of Burope, risiting the various sohools for the blind and studied all that had been done in the field of blind edueation and training. In his report Dr. Howe declared that the Royal Asylum for the Blind at Edinburgh was the best in Europe. "It comes nearer than any other to the attainment of the great objeot of blind sohools, viz., enabling the pupils to support themselves by their own offorts in after life." ${ }^{l}$ Dr. Howe brought back with him from Europe two assistants, Plerre Trensherio, of the Paris Institute, for the literary studies, and John Pringle, of Edinburgh, for the handiorafts. The sohool was opened in August, 1832, in a house belonging to Dr. Howe's father, with but six pupils. Although the school was located in Massachusetts, it was intended to educate ohildren from all the New Bngland states. Very soon after the opening of the school, each New England state made arrangenents for oducating its blind ohildren in Perkins Institute. South Carolina, in 1843, also made provision for obtaining instruction for her blind children in the lassachusetts institution. 3

In developing his program of blind education, Dr. Howe had one intention foremost in his plans, viz.. "to seok for the means of enabling the blind to beoome, in spite of their infirmity, active and happy members of society....." to "supply them with resouroes which make their existeneo no longer a burden to themselves and others, "enabling them "to fill a place in society and to take part in the pleasures and duties of life," and to "feel that they have something worth living for, and

1. French, op. oit., p. 107

2. Ibid.. p. 115

3. Best, 오. 오t., pp. 309-310 
that they are no longer dromes in a hive of busy bees." maintained that the eduoation of the blind would be a matter of oconomy to the oomunity. By this means, it would "take from society so many 'deadweights' and enable them to get their own livelihood; and sooiety ought to consider any capital so invested as a 'sinking fund' for the redemption of its charitable debt; as a provision for preventing the blind from becoming taxes on the community. ${ }^{2}$

From 1833 to 1835 the growth of the Boston institution was so rapid that it had to enlarge its quarters. In 1839 the sohool moved from the site on Pearl Street to new location in South Boston, and was thereafter known permanently as the "Perkins Institution and Nassachusetts Asylum for the Blind."

During these busy years, Dr. Howe found time to experiment with some new apparatus and appliances for the use of the blind. After a careful study of all the forms of embossed print then in use, he invented the "Boston Line Letter" which has been used for many years in the field of blind literature. He raised funds for seouring a printing press, gained the oooperation of the American Bible Society in the production of plates for the printing of the Bible, and "began to turn out additional literature at a rate astonishing to the slow-oreeping institutions of Europe. Within a few years the whole Bible was in the hands of the blind besides such a wealth of books as Hauy and his early suocessors had only dreamed of. $n^{3}$

Dr. Howe also made another historical edueational experiment, while conducting the Perkins Institute -- the instruction of the deaf-

1. Fronch, op. oit., p. 117

2. Ibid.. p. 117

3. Ibid.. p. 120 
blind Laura Brigman, the forerunner, and later teacher, of Helen Keller. This experiment established Dr. Howe's fame as an edueator of the sightless. However, he did not confine his work to them alone. He gave mueh of his onergy and time to the education of idiots, in the care of prisoners and of the insane, and in the promotion of the antislavery cause, "wherein his distinguished wife, Julia Ward Howe, figures so largely."l Nor did he confine his efforts to the state of Massachusetts alone. He soon became a "oircuit rider" for the ostablishment of schools for the blind in other States. With his pupils he appeared bofore the legislatures of a number of states to urge the oreation of similar institutions for the blind. 2

Although the Boston sohool has the distinetion of being the initial school for the blind in the United States, having been incorporated in 1829, a Now York sohool was the first to go into actual operation, March 15, 1832. The New York Institution for the Education of the Blind was founded as a result of the interest of certain philanthropists in several blind children in the almshouse. This institution was under the guidance of Dr. John D. Russ, and opened with only three pupils, all from the almshouse. Both state and private donations supported the maintenance of this school, to which were added the proceeds from fairs and exhibitions of pupils. In 1836, the state of Now Jorsey began to send pupils to it. 3

As early as 1824, the Sooiety of Friends had become interested In the education of the blind in Pennsylvania. However, not until 1833 ,

1. Ibid., pp. 120-121

2. Best, op. ait., p. 310 footnote

3. Ibid.. pp. $310-311$ 
one year after the Boston and New York sohools had opened, was the Pennsylvania Institution for the Instriation of the Blind founded. Dr. Julius Friedlander, a native of Germany, was appointed superintendent. This school, like the two preceding it, raised the funds necessary for its maintenance by fairs, subsoriptions and oxhibitions, until the state appropriated $\$ 10,000$ for its continuance. The pupils from this sohool were sent on exhibitionary tours to the noighboring States, "with the result that provision was made for the education of bliad children at this sohool by Dolaware in 1835, by New Jersey in 1836, and by Maryland If 1837.1

The fourth sohool to be created for the education and instruction of the blind of the United States was founded in Columbus, Oh10, in 1837, largely as a result of the exhibition given in that state by the pupils of the Massachusetts sohool. The Ohio Modioal Sooiety also agitated in favor of oreating an institution for the eduation of the blind, after a survey conducted by that body showed that there were some two hundred fifty blind persons in the State in 1834. The establishment of the Ohio school marked a ohange in polioy in the education of the blind. Honoforth, all such sohools, with few exceptions, were entirely under the direction of the State, and not under the control of private societies. 3 The institution at Staunton, Virginia, established in 1839, was found in much the same mannor as the Ohio sohool -- as a result of the appearances of pupils of the Massachusetts sohool, to whioh were added exhibitions by pupils from the sohool in Ohio. Three years later, the Kentucky Institution for the Education of the Blind opened its doors in

1. Ibid., p. 31; also footnote, p. 31

2. The excoptions were Maryland, one or two sohools of New England, and a sooond one in Pennsylvania.

3. Best, og. eit., p. 312 
Louisville, and the following year saw a private institution opened in Teanessee, whioh, two years later, was adopted by tho state. During the sucoeding years, as a result of much publicity and propaganda, sohools for the blind were opened in many of the other states: Indiana in 1847, Illinois and Mississippi in 1848, Wisconsin in 1849, Missouri in 1850. In 1851, a sohool for the blind was opened in Goorgla, although since 1846 the blind had boen instructed in the State sohool for the deaf 3 a department for the blind was created in the sohool for the deaf in North Carolina that same year. Iowa opened a private sohool for the blind in 1852, only to have it taken over by the State the following year. Maryland's sohool was commenoed in 1853 , and in 1855 a department for the blind was started at the South Carolina sohool for the deaf. In 1856, Texas opened her sohool for the blind, and Louisiana added a blind department to her school for the deaf. Thus, by the middle of the nineteenth century, twenty-five years after the opening of the first sohool, institutions for the blind were in operation in nineteen States of the Union. ${ }^{1}$ since that time, other States have oreated similar institutions, and the present time, every state in the nation makes some provision for the education of their blind. The great suesess and progress of these institutions for the instruction and eduoation of the blind in the United States is due largely to the intents and purposes for which they were oreated -- that overy person, whother physically perfect or handicapped, is entitled to on education, that no one should be donied this privilege, and that the State should make provision for those, who, because of their infirmities, would be unable to attend the comon sohools. The institutions for the

1. Best, 오. 1t., pp. 311-312 
blind in the United States have not been oreated, as have the European schools, with the idea that what is done in the way of edueation for the blind is done in the spirit of favor and charlty, but rather with the idea that it is the blind person's right and privilege so to be instructed. The policy previling in the Ameriean schools helps to give the blind a feeling of usefulness, self-respect, and independenoe, which is the right which all froe men should onjoy. In carrying out this polioy, the Kentucky school was one of the earliest and throughout its long and erentful history made many important and valuable contributions in the field of blind instruetion and training. 


\section{CHAPTER II}

FORMATIVE YEARS, 1842-1844

\section{1}


The Kentuck Institution for the Bducation of the Blind, now loeated at 1867 Frankfort, Aremue, Louisville, Kentucky, was founded by a charter from the General Assembly of the Commonwealth of Xentuoky, approved February 5, 1842. ${ }^{1}$ It is the home of the sixth institution of its kind in the United States, the first to be established In the south, and owes its inooption and early progress to two wellknown Kentucky citizens, Judge William Fontaine Bullock and Dr. Theodore Stout Bell.

Judge Bullock, son of Edmund Bullook, a former LioutenantGovernor and member of the House of Representatives, 1807-1817, was born January 18, 1807, in Loxington, Kontuoly, After graduating from Transylyanla Unirersity at the age of serenteen, he moved to Louisville in 1828 and practiced law until he rotired from active life at the age of seventy-five. In 1838, 1840, and 1841 he represented the Louisville district in the Kentuoky Legislature, and during his torms introduced a bill whioh established the common sehool system of the State. ${ }^{2}$

On Monday, January 3, 1842, "on motion of Mr. William F. Bullock," a bill was read in the House "to establish the Kentuoky Institution for the Edueation of the Blind. ${ }^{3}$ The bill was referred to the Committee on Education, and on January 14, 1842, was again read bofore the House. 4 The third reading of the bill before the House, on February lst of that year, proved conolusire, as the bill was passed without amendment. 5

1. Aots of the General Assembly of Kentuaky, A. G. Hodges, State Printer, Frankfort, 1842, pp. 26-28. See also the Appendix of this thesis. 2. Glenn G. Clift, Governors of Kentucky, Hobson Press, Cynthiana, Ky.,

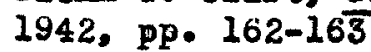

3. Kentuoky Leglslature, Journal of the House, 1841, P. 47

4. Ibid... p. 124

5. Ibid., p. 338 
The same bill, when introdueed in the Senate, was reoeived favorably, and was passed on February 2, 1842 by an almost unanimous vote. 1

The preamble to the original act stated that an equal opportunity for securing an eduoation should be extended to all children of the State, irrespective of their physical handioaps. Therefore, each sohool should share in the fund which the State had established for the Common Schools. ${ }^{2}$ Consequently, an appropriation of $\$ 10,000$ was made to be paid out of the interest on certain bonds held by the Kentuoky Board of Bducation. 3 At the time, however, some doubt was expressed concerning the legality of these bonds.

These bond's had been issued fraudulently by the agent of the State of Kentucky, and at the date of the act referred to, it was seriously doubted whether these bonds thus fraudulently issued would be recognized by the State. At that time efforts were made by agents of the state to trace the bonds, and thus relieve the state from their payment. The donation, therefore, to the institution for the blind was deemed of very doubtful value. 4

Although an act chartering the Kentucky Institution for the Education of the Blind had now been passed, the State was still somewhat dubious as to the foasibility of the undertaking, and before assistance of any sort would be rendered the institution, the school had to be established and operated successfully for twelve months.

It was thought best to proceed in the most cautious, prudant, and economical manner until the results should amply vindicate the polity and utilfty as well as the beneficence of the philanthropic enterprise.

1. Kentucky Lecislature, Journal of the Senate, 1841, pp. 221, 228

2. Aots of the General Assembly of Kentuoky, 1842, p. 26

3. Ibid., B. 28

4. F. A. Battey and Co., Kentucky, A History of the State, Sixth Edition, Louisville, $\mathrm{Ky} \cdot, 1887, \mathrm{pp} .536-537$; Roport of the Kontuoky Institution for the Blind, 1882, p. 7

5. Ibid., 1851, p. 3 
In order to arouse public interest in establishing other schools for the blind throughout the country, Dr. Samuel G. Howe, superintendent of the Massaohusetts sohool for the blind, and Mr. william Chapin, superintendent of the institution for the blind in Ohio, oame to Kentuoky with some of their blind pupils and gave an exhibition before the legislature at Frankfort, and in the churches of Louisville, I "Suoh practical illustrations of the good results from educating the blind proved irresistible arguments with the members of the Legislature and created a deep interest in the welfare of the school." ${ }^{2}$ So much enthusiasm was manifest among the oitizens of Louisville, that a committee of twenty-one persons was appointed to colleot money to support the sohool for one year. 3 These funds were raised by popular subscriptions and by fairs conduoted by the ladies of Louisville.

Acoording to Seotion One of the Charter, the school was to be under the government of seven Visitors, to be appointed annually by the State Board of Eduoation. However, the first Board of Visitors was composed of three members only -- Mr. William F. Bullook, Presidents Samuel Casseday, Treasurer; and Bryce M. Patten, Secretary • Mr. Patten was also appointed Director and Superintendent of the school, having been called to that position from the Collegiate Institute of Loulsville, where he had formerly been a prinoipal. 4

Immediately after their appointment, the Visitors made arrangements for the opening of the school. Mr. Otis Patten, brother of the

1. Battey and Co., op. oit., p. 537; J. Stoddard Johnston, A Memorial History of Louis ilile, Vol. II, P. 290

2. Johnston, op. olt., p. 290

3. Battoy and Co., Op. oit., p. 537

4. G. Collins, Louisvillo Directory, 1843, p. 29 
superintendent, and a former pupll at the Massachusetts sohool for the blind, was seleoted as a teacher; Mrs. E. M. Boynton, as a matron; and Miss Elvessa J. Ruth, teacher in the girls' department. ${ }^{1}$ A suitable house, located on Sixth Street, west side, between Chestnut and Walnut, was rented from H. Knott and furnished by the "liberality of the citizens of Louisville."n2 Enough funds were oontributed to sustain the institution during the first six months of its existence. ${ }^{3}$

As means of attraoting pupils to the school, a ciroular was is sued and extensively oiroulated throughout the state, "giving notice of the opening of the Institution, making known its nature and objects, and solioiting pupils and information respecting blind ohildren from all sections of the State." ${ }^{4}$ With but five pupils enrolled, the sohool opened on the ninth of May, 1842. In the course of the year, five more pupils were added, making the total number ten, "all of whom are supported by the Institution, except one, who pays a part of his expenses." 5 The following table contains the names, places of residenoe, dates of admission and ages of the pupils $:^{6}$

Name
Sarah J. Clark
Araminta A. Hodge
Elressa J. Ruth
Sarah J. Lund
John A. Metcalf
Jonathon Sands berry
Franois Ratliff
Samuel Seay
Mary A. Gibson
Pierce P. Prioe

Residence
Jefferson Co.
Louisville
Louisville
Louisville
Louisville
Jefferson Co.
Daviess Co.
Hashington Co.
Louisville
Louisville

Date

Afe

May 9,1842

May 9,1842

May 9,1842

May $9,1842 \quad 16$

May 9,184210

June $6,1842 \quad 16$

oct. $26,1842 \quad 18$

Nov. $21,1842 \quad 16$

Dec. $28,1842 \quad 18$

Jan. 4, $1842 \quad 7$

1. Report of the Kentucky Institution for the BIind, 1842, p. 273

2. Johnston, op. oit., p. 290; Heport of the Kontuoky Sohool, 1891, p. 8

3. In a communioation from the Trustees, published in the Louisvilie Journal of May 14, 1842, speoial mention is made of the industry and zeal of James S. Speod, Joseph Matoalfe and Samel Dickinson in procuring subscriptions; also to the pupils of Miss Mason's Sohool for the proceeds of concerts given in aid of the Institution.

4. Report of the Kentucky Institution for the Blind, 1842, p. 274

5. Ibid., p. 274

6. Ibid., p. 274 
Shortly after the opening of the Institution, three now members were added to the Board of Visitors: Dr. Theodore S. Bell, John I. Jaoob, and James Pickett. Dr. Bell not only served as a member of the Board, later becoming its president (1864-1880), but was also the medical adviser for the institution for the first few years of its existence. He was keenly interested in the welfare of the blind throughout the State and gave unoesaingly of his time, influence, and personal exertions to promote and expand the program for their education at the Kentuoky sohool. He never missed a meeting of the Board of Visitors during the entire time he was a member. Besides his interest in the Kentuoky Institution for the Bduoation of the Blind, Dr. Bell was one of the founders of the Louisville Medical Institute, whioh subsequently developed into the University of Louisville. 1

The first set of regulations governing the institution oontained the following rules of admission:

No person can be admitted as a pupil who is under six or over fifteen years of age, unless by special rote of the Board of visitors. Candidates for admission must present oertificates from some respectable physician of inourable blindness, and of freedom from epilepsy, and all of fensive and infeotious diseases. They must bring satisfactory testimonials of unexceptionable moral charaoter.

All male pupils must be provided with at least fivo shirts, two vests, two coats or jackets, two pairs of pantaloons, six pairs of socks or stookings, two stocks or oravats, four pooket handkerohiefs, two pairs of boots or shoes -- all in good condition.

The fomale pupils must be provided with at least three ohanges of garment. All the artioles of elothing mast be marked with the name of the owner. The olothing must be renewed by the parents or friends of the pupils from time to time, as may be nocessary. 2

The expense for maintaining pupil in the institution for one school year (ten months) were two hundred dollars, "for board, tuition, washing, music, books and stationery." Provision was mado, however, for

1. H. A. Kolly and W. L. Burrage, Diotionary of Amerioan Modical Biography, pp. 91-92

2. Report of the Kentuoky Institution for the Blind, 1842, p. 275 
the indigent blind of the State. Such pupils were to be educated at the expense of the Institution. ${ }^{1}$

As a means of helping the Institution defray the expense of educating the indigent pupils, the Kentuoky Board of Eduoation, in accordanee with the aot of the Legislature of the previous session, appropriated during the year 1842-1843 the proceeds of the dividends upon seven hundred and thirty-fire shares of stock of the Bank of Kentuaky to the Kentucky sohool for the blind. The totel proceeds derived therefrom amounted to $\$ 1,102.50$, and the share which the school received amounted to $\$ 775.00$, leaving the Board of Eduoation indebted to the school for the sum of $\$ 327.50 .^{2}$ The appropriation was greatly needed by this embryo institution, as most of the pupils were indigents, and therefore beneficiaries of the sohool.

During the first year, the strictest econony had been adhered to by the sohool, as the funds for its operation were not large. Donations amounting to $\$ 622.50$ by the citizens of Louisville, and $\$ 775.00$ from the Common Sohool Fund (a part of the $\$ 10,000.00$ appropriated by the General Assembly in the original act chartering the sohool), conprised the entire receipts for the year, a total of $\$ 1,397.50$. The expenditures up to the first of January, 1843, amounted to $\$ 1,041.96$, leaving in the Treasury $\$ 365.54$. The Treasurer also had numerous uncollected subscriptions, amounting to $\$ 650.00 .^{3}$ Despite the diffioulty of obtaining appropriations, and the number of charitable pupils enrolled in the sohool, the Kentucky Institution for the Bduoation of the Blind had suocessfully survived its trial year of operation, and was ready to

1. Ibid.. p. 275

2. Kentuoky Documents, 1842-1843, "Fifth Annual Report of the Superintendent of Public Instruotion," pp. 241-242

3. Report of the Kentucky Institution for the Blind, 1842, pp. 274-275 
take steps toward establishing a more permanent sohool.

Before the blind sohool had been in operation two months, the Trustees of the Institution and other altisens of the city were well pleased with its progress and developments. In his first annual report to the Board of Bduontion, Mr. Patten, superintendent of the blind sohool, made the following statement concerning the progress of his pupils:

In a few months the ohildren wore abl to read with considerable fluenoy in the Bible and other books printed for the blind. Several write a legible hand, and oan correspond with their distant friends by letter. Thoy write with a lead penoil instead of a pen, as a blind person oennot see to the regular supply and flow of the ink, nor the perfeotion of the pen.... Most of the pupils have made good progress in Arithetio and Geography. Several beautiful maps have been receired recently, on which they feel out rivers, lakes, bays, ooeans, mountains, towns, eto., with surprising facility .... In misic the pupils take great delight, and their progress has been most satisfaotory. All oan sing -- some very well -- and two little girls, thirteen years of age, perform on the piano. This branoh is a very important one in the education of the blind, as it is not only a source of great pleasure to themselves and others, but affords to many of them a respeotable means of support as organists, tuners of instruments, and teachers of vocal and instrumental music.1

By January, 1843, the blind school found it neoessary to move to another looation, and this time the "Prather House," on Green Street (now Liberty Street), between Third and Fourth Streets, was leased. 2 At this location the school oontinued to expand in enrollment; nineteen pupils were received, fourteen of whom were beneficiaries of the State.

In July, 1843, the Board of Visitors borrowed from the Bank of Louisville the sum of $\$ 1,500.00 .^{3}$ The money was used to purchase a lot "on the south side of Broadway, between First and Second Streets, one hundred and forty feet front and four hundred foot deop. $n^{4} \mathrm{Mr}$.

1. Ibid., 1842, pp. 274-275

2. Johnston, op. cit., p. 290

3. Report of the Kentuoky Institution for the Blind, 1843-1844, p. 461

4. Johnston, op. olt.. p. 290. This lot is at present oocupied by St. Xavior High Sohool. 
John I. Jacob, a member of the Board of Visitors, from whom this property was purchesed, "sold the land, July 19, 1843, for less than half the price his ground was yielding him alongside of it. He thus made a donation of between fifteen hundred and two thousand dollars to the Institution." 1 This was the first step toward establishing a permanent home for the Kentucky blind institute. In his second annual report to the State Board of Education, Mr. Patten made urgent pleas for appropriations by the Legislature for the erection of a permanent building to house his worthy school.

The house now occupied by the Institution will not accommodate more than the present number of pupils; besides, the lease on it will expire in Auguat next, and it is not probable that it will be renewed. It becomes, therefore, the duty of the Board of Visitors to recomend, that provision be made by the Legislature for the erection of a suitable edifice for the accommodation of the Institution. A draft for suoh a building as is deemed desirable, presented to the Board by wir. J. Stirewalt, a distinguished architeot of this oity, will probably be exhibited to the members of the Legislature during the present session. The Visitors have practiced, and will continue to practice, the most rigid economy; but when it is proposed to erect an edifice, which, for generations to come, is to be the home of the blind youth of Kentucicy, and perhaps of some of the sister states, which is to be one of the chief ornaments of this Commonwealth, and which, from its geographical position, eill, probably at no distant day, take the lead, and in respect to numbers, of all the Blind Institutions in the Union, we would recommend liberality. Kentucky has provided nobly for the Deaf and Dumb -- she has erected a stately edifioe for the Insane, and the Institution for the Blind looks up, with oonfidence, and asks that in its infancy it may be fostered; and we trust that this appeal to the Legislature as enlightened as that of Kentucky will not be disregarded.2

Hence, on February 29, 1844, the General Assembly of the

Commonwealth of Kentuoky passed an act for the benefit of the Kentucky

Institution for the Education of the Blind which stated:

that the sum of five thousand dollars $b_{\theta}$, and the same is hereby appropriated for the erection of a suitable building for the Kentucky Institution for the Eduoation of the Blind, which sum shall

1. Report of the Kentucky Institution for the Blind, 1848-1849, p. 13; City of Louisville, Deed Book Bo. 61, pp. 47-48

2. Report of the Kentuchy Institution for the Blind, 1843-1844, p. 465 
be paid out of any money in the Treasury not otherwise appropriated, subjeot to the order of the President and Visitors of said Institution; Provided, however, that this appropriation shall not be expended otherwise than in the completion of a convenient building for the present acoommodation of the pupils of said Institution; and the Direotors are hereby directed to contract for this erection and completion of said building, so that it shall not cost beyond the amount of means fully within their power at the time such contract shall be made.l

In addition to this legislative appropriation, the Institution pledged the sum of $\$ 3,382.00$ toward the completion of the building. This sum was the balance remaining in the school treasury at the end of the year, $1843-1844 .^{2}$

During the year 1844, Mr. Patten, superintendent of the institution, made several excursions throughout the State with some of his pupils and gave exhibitions of their attainments. These excursions were undertaken for a number of purposes. The exhibition before the Kentucky General Assembly was intended to convinoe the legislators of the value of educating the blind of the State, that theirs was not a hopeless plight, but that they could and should be given "a sound mind in a sound body." The exhibitions given in Now Albany, Indiana, and in Covington, Maysville, Nicholasville, and Lexington, in this state were intended to diffuse among the people information with respeot to the wants and capabilitios of the blind, and also to attract more pupils to the school. Many parents of blind children believed that in sending their unfortunate offspring to the school they were committing them to an asylum for life. Of course, this conviction was erroneous, as the children were allowed to return to their homes each sumer, and the parents were welcomed to visit the school at any time.

1. Acts of the General Assembly of Kentucky, 1844, p. 51

2. Report of the Kentucky Institution for the Blind, 1844-1845, p. 4 
During the 1844 session of the General Assembly of Indiana, Mr. Patten accepted an invitation to visit Indianapolis with some of his pupils, and gave exhibitions before the Legislature. "So great was the interest awakened, that an appropriation will probably be made for the support of the indigent blind children of that state." 1 Thus, in the same manner by which the Massachusetts and Ohio schools for the blind helped to start the movement for blind education in Kentucky, so the Kentuoky sohool was the incentive whioh started the eduation for the blind in Indiana, for in 1847 the Indiana school for the blind was chartered. 2

Owing to the increasing cost of operating the Kentucky sohool for the blind, the Board of Visitors made another plea early in 1844 to the State Legislature to appropriate some money for its continued operation. In order to ralse the necessary funds, the state embarked on a scheme, which, if it had been successful, should have given marked financial assistance to the school. On March 2, 1844, a charter was obtained from the General Assembly establishing a corporation "to run a line of cars with steam as the motive power between Louisville and Portland, then three miles distant, and an important shipping point on account of the difficulty of navigation in low water." 3 The incorporators were: William F. Bullook, John I. Jaoob, Samuel Casseday, T. S. Bell, James Pickett, David L. Beatty, Fred A. Kaye, Elisha Applegate, William E. Glover, William E. Field, E. G. MoGinnis, Bryoe M. Patten, Andrew Graham, Reuben Dawson, Garnett Duncan, Jabez Baldwin, J. W. Knight, Charles J. Clarke. The road was capitalized at $\$ 100,000$

1. Ibid., 1844-1845, p. 8

2. Best, op. cit., p. 314

3. Acts of the General Assembly of Kentucky, 1844, p. 91. The road had formerly been part of the old Lexington and Ohio Railroad (see Johnston, op. o1t., p. $320 \%$ 
and a portion of the stook was to be taken and paid for by the state, and it was to be operated for the benefit of the Kentucky Institution for the Education of the Blind. ${ }^{1}$ It is thought that this road was a portion of the old Lexington and Ohio Railroad; however, there are no authoritative records concerning its origin. The undertaking to maintain and operate the Louisville and Portland Railroad for the benefit of the blind school proved unsucoessful, as the road required a largo sum of money to keep it in neoessary repair. Hence, on January 8, 1845 , the Board of Visitors received the following communication from the President and Secretary of the Board for the Louisville and Portland Railroad Company:

Immediately after the organization of the Board of Managers, in April, 1844, a thorough examination of the condition of said road was made. It was found that a large sum of money would be required to place the road in a condition to be at all beneficial to the Institution for the BIind; and it was, therefore, determined, to save from loss, with the least expense, whatever belonged to said road; this has been effected, thus far, by letting said road for the small sum of sixty dollars. We are of the opinion that this cannot be longer done than April next. If we are right in this conjecture, then the iron rails must be taken up, and, together with the other apparatus, stored away, to proteot them from loss, which will require an expenditure of money much larger than the sum received. 2

According to the report of 1846, "No income has been recelved the last year from the Louisville and Portland Railroad Company, the road remaining in the same condition as was stated in our last anmual report. "3 The financial statements of the sohool for the years 1847 and 1848 show no recelpts gained from nor any expenditures made to the railroad. In considering the financial resources of the institution, the Report of the Board of Visitors for the year 1848 states: "Should

1. Aots of the General Assembly of Kentucky. 1844, pp. 91-94

2. Report of the Kentuaky Institution for the Blind, $1844-1845, p$, 4 3. Ibid.: 1846, p. 10 
nothing be realized from the 'Loulsville and Portland Railroad," of which there appears, at present, but little hope, it will doubtless be neoessary by some other provisions, to supply the deficienoy caused by the failure of this enterprise." I In 1849 the report is mades.

.... the most material disappointment has arisen from the failure to derive any benefit from the oharter of the Louisville and Portland Railroad Company. while we are confident that we may, with suitable amendments to the charter, look to the completion of that improvement as a souroe of support to the sohool, we have to report that we have not, as yet, derived any income from it. Various causes have combined to prevent the successful prosecution of the work. The Institution for the Blind having no means at its disposal for the construction of the road, the Railroad Company was compelled to barter the privileges of the charter to capitalists.

No responsibility, with respect to the construction of this road, was bestowed on the Trustees of the Institution; but an independent Board, to whom was committed that duty, was appointed by the Legislature. Notwithstanding this, such was the interest felt by the Trustees, in enlarging the usefulness of the school entrusted to them, that they lavored as sedulously in endeavoring to prepare the way for the oonstruotion of the road, as if that duty had been assigned to them by the General Assembly. As a Board, we bear testimony to the zealous and effiolent labors of two gentlemen, espeoially, who were, at the time, our colleagues, in furthering the objects of the Railroad charter. By their diligent and laudable exertions, the subscription of stock, to the full amount of the capital of the Company, was secured. The chartered rights, bestowed in favor of the Institution, were then transferred to the stockholders, on the best terms that oould be obtained; and if the improvement could have been made, we doubt not that the Institution for the Blind would have been placed in a prosperous condition. But the body to whom the General Assembly committed the duty of constructing the road, failed to accomplish the work. It was found impossible to obtain the right of way through Portland, on such terms as were deemed proper. The municipal authorities of that town felt themselves bound to proteot the interests of the wharf, that had oost them a large sum of money; and, in the protection of those interests, there were diffioulties presented, under the present charter, which materially interfered with the construction of the road. With the municipal authorities of Louisville, also, difficulties presented themselves. Those authorities refused the right of way through the streets of the city, on any terms, under the present arrangements of the charter; and the capital of the company was not sufficient both to construct the road and to force it through the city. But it is

1. Ibid., $1848, \mathrm{p} .12$ 
believed, that, with suitable amendments to the charter, we shall be able to command the co-operation of the authorities of Louisville. The Institution for the Blind has entirely failed to draw any support from this souroe, in accordance with the liberal intentions of the cieneral sssembly. But we are by no means disheartened. we feel confident that we shall be able, ultimately, to secure benefits to the institution from this Railroad charter, and thus relieve the State Treasury from a portion of its charge; and, in order to cormence new efforts for the accomplishment of this desirable object, we have called upon the President and Directors of the Railroad Company to racate the stock subscribed, and restore the charter to the corporators originally names by the Legislature. When the oharter is returned, application will be made to your honorable body, for some essential amendments, which cannot fail to command your favor; and we shall then hope to suoceed in constructing the road.

In 1850 it was reported, "No income has been derived from the Louisville and Portland Rallroad, although we have used all the means in our power to seoure the reconstruction of the road." 2 The financial statement in the Report for 1851 shows that the sum of $\$ 800.00$ was derived from the sale of old railroad iron. 3 On January 5, 1852, the General Assembly authorized the Board of Visitors of the blind school to sell the charter of the railroad to a company for the sum of six hundred dollars per annum, the first payment to be made in eighteen months from the date of contract. Although no mention is made in the Report of the school concerning this act, the biennial report for the years 1854 and 1855 shows in its financial statement a receipt of $\$ 600.00$ from the Louisville and Portland Railroad, as well as $\$ 1,048.35$, "prooeeds of sales of old railroad iron." 4 The railroad charter was sold to Isham Henderson, who converted it into a street railroad, operated by horse power. "It is the plonear in street rajlroads in this country, and beoane the nuoleus of our present system." 5 Thus, the first large-scale economio enterprise undertaken for the benefit of the blind sohool came to a very unfruitful conclusion.

1. Ibid., 1849, pp. 5-6

2. Ibid., $1850,5.8$

3. Ib1d., 1851, p. 8

4. Report of the Kentuoky Institution for the Blind, 1854 and 1855, p. 7

5. Johnston, op. olt.. Vol. I, p. 320 
CHAPTER III

A DECADE OF PROGRESS, 1845-1855 
CHAPTER III

In July, 1845, the first permenent home of the Kentucky Institution for the Eduoation of the Blind was ready for ocoupation. A oomplete desoription of the building appeared in Mr. Patten's Anmual Report to the Leglslature for that year.

The new edifice, though commodious and beautiful, has been built in the most economical manner, and on the most favorable terms, as all admit, who compare the cost of the work with the extent and charaoter of it. The building is ninety-six feet in length, fifty feet in width, three stories high, and contains thirtyfive rooms, one of whioh is a hall for concerts, exhibitions, otc. 'hough complete in itself, it is, in accordanoe with the directions of the General Assembly, so construoted that it can hereafter be enlarged by the addition of one or two wings, should the inorease in the number of pupils ever require it. 1

An interesting account of the new location of the sohool --

Broadway between First and Second streets -- appeared in the Serenth

Annual Report of the Board of Visitors to the Generil Assembly, 1848,

It is true that the institution is in the "suburbs of Louisville" but the improvements of the city are so rapidly extending in that direction, and even beyond the institution, that it is probable that it will very soon be entirely surrounded by a thriving and respeotable population. It is convenient, by means of paved streets, to the whole olty; and if a sufficient quantity of the adjacent land oould be purchased, it is believed that a more oligible site for such an Institution, could not be obtained .... within the limits of the oity ....

In the immediate vioinity of the Institution for the Blind, the Jesuits purchased ground for the erection of a great lollege, which they were ordered by their superiors to abandon for want of funds ....

The land on the west of the institution is annually cultivated; the land on the south is noither marshy nor malarial, and a number of dwelling houses have been erected on the eastern side of the institution, and immodiately alongside of it. In front of the Institution, Broadway has been graded and peved, for which the Mayor and Counoll of Louistille liberally paid, instead of taxing the State with the expense.2

2. Report of the Kentucky Institution for the Blind, 1844-1845, pp. 4-5

2. Ibid., 1848, p. 14. The lot is at present occupied by the St. Xavior High sohool, having been purohased in 1891 from the lewoombe family, residents on that property sinoe May, 1856, rrior to 1855, the property belonged to Messrs. S. R. Smith and William Walker who had purchased it from the Blind Institute in 1852. (See Louisville Deed Books: Grantor to Grantee, 1852, 1855; Grantee to Grantor, 1891.) 
By 1846 the enrollment of the sohool numbered thirty-one pupils, of whioh twenty-one wer received as benefioiaries of the State. The expenses for paying pupils had been reduced from two hundred to one hundred dollars per capita per annum. The school received an appropriation of one hundred twenty dollars per annum for each indigent pupil received by the Institution. This was in acoordanoe with an act passed by the General Assembly on February 8, 1845, whioh further provided:

.... that no scholar shall be taught at the expense of the state more than five years; and provided, alse, that the sum so to be drawn from the Treasury, shall in no one year exceed the sum of two thousand five hundred dollars. 1

The same act provided that the Kentuoky Institution for the Education of the Blind might receive pupils from other States, "provided the expense of their maintenance and tuition be defrayed by such State or States, or by some individual or society; provided, that such admission shall not operate to the exclusion of any indigent pupil of the State of Kentucky $n^{2}$ In 1846 six ohildren not residents of Kentucky were admitted to the school. One was sustained by the Poydras Female Orphan Asylum of Now Orleans, and five were supported by the state of Indiana, the latter as a result of Mr. Patten's visit to that State in 1844.

Great aare was taken to admit to the Institution only those pupils who showed promise of being benefited by their edueation at the blind school, and any ohild who did not appear to grasp the work at the school, was not retained. "The Institution is striotly a school f'or the education of the blind youth of good mental capacity, and not an asylum for the old or imbecile, for whom suitable asylums should be, and are elsewhere provided, as they can derive but little advantage

1. Acte of the General Assembly of Kentucky, 1845, p. 45

2. Ibid., 1845, p. 45 
from associating with the young and active, while the latter may suffer immensely from suoh association. ${ }^{1}$

By an act of the General Assembly, approved February 23 , 1846, the sum of $\$ 3,500$ was appropriated to the Institution, "a part of which was to be applied to the payment of the debts of the Institution; and the balance to the purchase of a suitable library, apparatus, instruments, and the ereotion of the necessary improvements, for the use of the Institution ...." 2

The sohool already had a small library, made up of the following books printed in embossed type:

Name of Book
The Bible
Book of Psalms
Book of Proverbs
Ruth and Esther
Guide to Spelling
Seleot Library
molish Gramar
Howe's Geography
Atlas of the United States
Goneral Atlas
Atlas of the Islands
Student's Magazine
Virl Romae
Book of Diagrams

$\begin{array}{cc}\text { Number of copies } & \text { Volumes } \\ 2 & 16 \\ 2 & 6 \\ 6 & 1 \\ 1 & 1 \\ 1 & 3 \\ 3 & 4 \\ 1 & 1 \\ 1 & 1 \\ 1 & 1 \\ 1 & 2 \\ 2 & 1 \\ 1 & 1 \\ 1 & 1 \\ 1 & 1 \\ 1 & \end{array}$

In addition to these volumes, the library also inoluded a number of maps and other apparatus :

5 Slate frames and types

I Map of the World

1 lap of Horth Amerioa

1 Map of the United States

1 Map of Kentucky and Tennesseo

1 hap of Burope

1 Map of Asia

1 Map of Africa

1 llap of South Amerioa

8 Writing oards

1 Printing Box

1 Piano Forte

1. Report of the Kentuoky Institution for the BIInd, 1846, 9. 7

2. Aots of the General Assembly of Kentucky, 1845, pp. 31-32 
To this maleus were added the following books, purchased as a result of the Aot of 1846,1

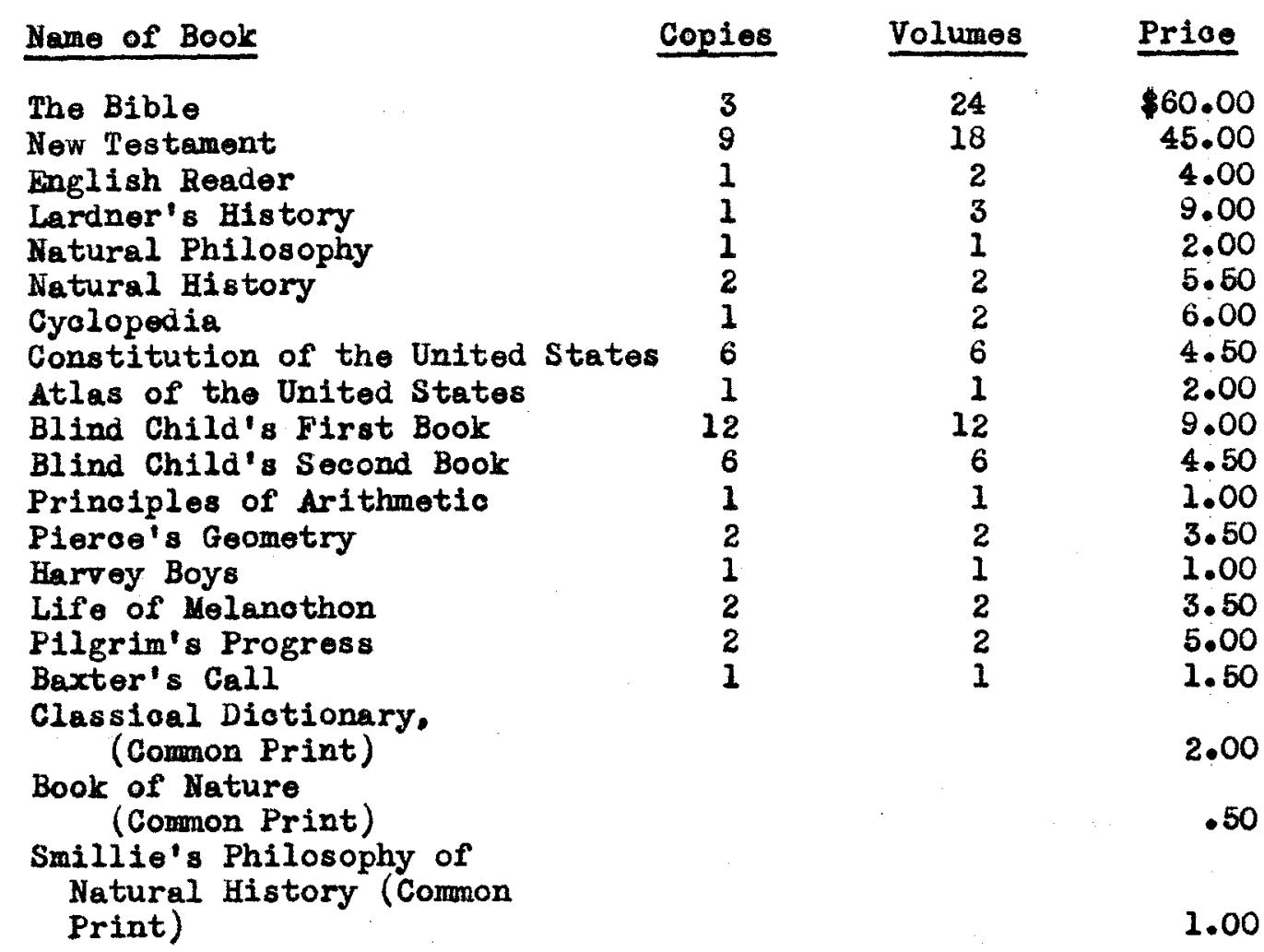

In addition to these books, the American Bible Society donated four copies of the Bible to the Institution for the use of indigent pupils. All of these books were printed in embossed, or raised, letters. The sohool also recoived from some friends of the blind, one hundred eighty volumes of books printed in the ordinary manner, or comon print, which the teachers or other officers of the sohool read to the pupils as occasion arose.

Although the enrollment in the Kentucky sohool for the blind continued to inorease year after year, the superintendent felt that the number represented only a small portion of the blind youth of the State eligible for admittance to his school. Consequently, In 1847 he again made numerous excursions throughout the State to disperse

1. Report of the Kentuoly Institution for the Blind, 1846, p. 9 
information concerning his sohool, thereby hoping to attraot additional pupils. Taking with him one or more of his pupils, he visited during that year the counties of Bullitt, Nelson, Hart, Barren, Green, Adair, Casey, Lincoln, Boyle, Mercer, Anderson, Shelby, Kenton, Campbell, and Boone. Concerning these visits, Mr. Patten made the follow-

Ing report to the Kentucky Board of Bducation:

The Director, in his expeditions, found many blind persons sitting in darkness, ignorance, and helplessness, without hope either for the present or future state of existence. Some of these were induced to enter the Institution, and they have already learned that the world presents, even to the blind, much of light, and hope, and happiness. Others, we regret to state, still drag out useless, misorable lives in their secluded homes - shut out from almost every means of physical, intellectual, and moral culture. This, however, does not result from indisposition on the part of the blind to avail themselves of the privileges offered to them in the Institution, whlch has boon establishod for their benefit. It most frequently results from ignorance on the part of parents as to the importance of education, or from their unwillingness to send from home, and intrust to the care of others, their unfortunate children, who are often the most interesting, and almost always the most beloved, of the family. Misfortune of any kind tends strongly to endear to parents tho child that is visited with it, and of all misfortunes, blindness, perhaps, has this tendency in the highest dogreo. To sever, in any measure, the bonds which affection and misfortune have combined to unite in the olosest ties, often requires a more powerful effort than parents are willing to make, though urged to it by conscience, and the entreaties of their unhappy children, who, sometimes, with tearful eyes, and the most eloquent petitions, so reasonable, and so well calculated to reach the heart of an affectionate parent, are sometimes disregarded, and the hapless petitioners consigned to other long years of rayless gloom and inaction. 1 .

On his expoditions throughout the counties, Mr. Patten not only induced many of the blind youth of the state to avail themselves of the privileges of the Institution, but bo al00 oolleoted important statistical information with regard to the blind of the State. The United States oensus did not furnish very reliable statistics concerning the unfortunate, and especially the blind. For correct information, each

1. Ibid., 1847, p. 7 
State had to rely upon some other source. Even the census of Kentuoky was not entirely acourate. Sereral disorepanoies were found in its statistics concerning the blind; for instance, Jefferson County, listed as having seren "blind persons of all ages," had already sent eighteen pupils to the Institution. ${ }^{1}$ Mr. Patten, therefore, appealed to the General Assembly to pass an act authorizing the County Commissioners to ascertain annually and report to the Secretary of State, the number of blind, deaf and dumb, and insane persons, in their respective counties, with the name and age of each. 2 This would be helpful and valuable information to the superintendent in his attempt to contact all the blind youth of the state. The requested aot was passed January 9, $1852 .^{3}$ However, this duty thus required of the County Commissioners was only partially performed in many of the counties, while in some counties it was totally neglected.

In 1849, Mr. Patten, with two of his pupils, visited the counties in the western section of the State, and again, in the principal towns, gave exhibitions of the attainments of his pupils, and the "mode of instruction" in the Institution. 4 Bverywhere he went, his exhibitions were received with great interest, and as a consequence many children entered the blind sohool, most of whom would never have reached the Institution had not this personal contact been made.

The number of indigent pupils admitted to the Institution was limited, for, in accordance with the act of February, 1845, no more than two thousand five hundred dollars was to be spent in their educa-

1. Ibid., 1848, p. 8

2. Ibid., 1848, p. 8

3. Ib1d.: 1854-1855, p. 9; Acts of the General Assembly of Kentucky. 1851-1852, p. 361

4. Report of the Kentucky Institution for the Blind, 1849, pp. 4-5 
cation. Henoe, not more than twenty-one indigents could be cared for in any one year. Since most of the blind of the state were of the indigent class, the Board of Visitors asked that the Legislature amend the act in order to provide for the maintenance of more pupils as beneficiaries of the state. Thus, in accordance with an act approved February 27, 1847, the Kentucky Institution for the Eduoation of the Blind was authorized to:

receive into said Institution any number of indigent pupils, until the entire number of beneficiaries of the State, ineluding those heretofore provided for by law, shall amount to forty .... Provided, that in order that all the oounties of the comonwealth may have opportunity to participate in the benefits of the Institution, no pupil may be received, under the provisions of this act, until the 15th day of June, 1847, from any oounty that has heretofore sent pupils to the Institution to be educated at the expense of the State: And, provided further, that whenever there are more applicants than can be recoived at one time, the Board of Visitors shall so apportion the number among the several counties, applying for the admission of pupils, that each county may receive its due share of the benefits of the Institution. 1

The reputation of the Kentucky Institution for the Eduoation of the Blind, its officers and pupils, was being widely spread throughout the Union. In 1847, after paying several visits to the Institution, Miss Dorothee Lymde Dix, the noted philanthropist and author, who devoted most of her life to the study of conditions of the unfortunates, espeoially of the insane, wrote the following words of commendation for the sohool:

The proficiency of the pupils is no less surprising than it is gratifying. They are thoroughly instruoted, and are remarkably fortunate in having competent teachers wholly devoted to their happiness and improvement. I have rarely visited any Institution for children and young persons, under State patronage, so thoroughly well organized, and so judiciously managed throughout, as is this. Go when you w111, at morning, noon, or evening; in storm or sunshine, expected or unlooked for, you will find that here's "A place for all things, all things in their place;" and so, too,

1. Aots of the General Assembly of Kentuoky, 1847, p. 33 
each hour marked by appropriate study, refreshment, labor, exercise, and rest. It is not possible to visit this Institution even but once, (my visits have been renewed and repeated) and not perceive that all is fair, open and true, in the domestic circlo, and in the school. There is no need to prepare for visitors, because, as in all rightiy regulated establishments, order, method, and good government so prevail, that you cannot find them at any time amiss. Careful attention is paid to the personal habits of the pupils. Cleanliness and neatness are obligatory. While the high-principled and disoreet superintendent of this sohool exacts the most correct habits in the pupils, the same are required of all the inmates; and while the mental oapacities are trained and educated, it is never forgotten that the moral nature is to be enligntened and directed, and the manners and conversations made to harmonize. A good example onforoes good counsels. Firmness, kindness, and fidelity characterize the teachers; obedience, good will, and industry, with but few oocasional exceptions, distinguish the pupils.

Here these children and young persons from whom the natural sun is veiled, who are, through privation of vision, prevented from joining in the general bustle, and oares, and amusements of life -here, they find happiness in the acquisition of knowledge, in the various exercise of their faculties, and in learning how, in time to oome, they may best benefit their friends and bocome useful members of society. The bounty of the State is here well bestowed: these blind, but intelligent children, will repay to the public an hundred fold all they are now receiving. Thoroughly educated, and trained to virtuous and industrious habits, they will not return to their own homes, without extending good influences in their own families and communities. They are taught that it is a duty they owe the state to be assiduous in study, and correct in habits. No harsh impositions or severe restraints enforce the one or secure the other.

It may be thought by some readers that possibly a too favorable estimate is placed upon the Louisville Institution by the writer. She can only say it is open to all, and of easy access; let the public and individualy judge for themselves. More might very justly have been added in oomendation, but it is unealled for; without ostentation it revoals and sustains a fair and beautiful character. I have, on my various and distant journeys, heard this school referred to by those persons who have oasually visited it, and on no single occasion have I heard it named in any but terms of confidence and interest. The attachment of the pupils of the Institution to their companions and teachers, is a guarantee that "all is well there" in the domestio and social relations.1

By 1848, there were four teachers on the faoulty of the Kentucky school for the blind: Mr. Bryce M. Patten, the superintendent, was the prinoipal teacher; his brother, Otis Patten, was also a teacher; Mr.

1. Report of the Kentucky Institution for the Blind, 1848-1849, pp, 9-10 
Joseph B. Smith came to the institution in 1844 to teach music and piano; Mr. William.D. Gotshall, a blind man educated at the Ohio Institution for the Blind, joined the faculty as a teacher of brushmaking. In October, $1847, \mathrm{Dr}$. K. C. Howitt was appointed physician to the Institution, having already given two years of gratuitous servioe to the sohool previous to his eppointment. Mrs. Sarah J. Smith, the matron, completed the roll of officers of the institution. On February 28, 1848, the General Assembly appropriated the sum of $\$ 5,000.00$ to the Kentucky Institution, "a portion of which shall be applied to the payment of the ordinary current expenses of the Institution, and the balance to the purchase of additional land, an organ, pianos, and the erection of a suitable workshop for the use of blind pupils."I The sohool had made repeated pleas for the appropriation for an organ, since many of the pupils could earn a living as organists in the various ohurches of the city.

The suitable workshop was a greatly needed addition to the Institution. From the beginning of the sohool's history, boys and girls working in the basement room had been making useful artioles, many of which were sold to the public, and the money derived thus went into a fund to help defray expenses of the sohool. Some of the items manufactured by the students inoluded: mattresses, brushes of varlous kinds, watoh guards, lamp mats, and fancy baskets. This meohanical department proved to be a self-sustaining and profitable branch of the school, and for a while business was such that a sales room was maintained in the heart of the business district. However, the expense of maintaining this sales room soon forced its removal

1. Aots of the General Ass embly of Kentuoky, 1848, p. 52 
back to the main building. In 1848, with the money appropriated by the General Assembly, a lot of ground was purchased on Broadway, east of the Institution, and small workshop ereoted. In this new workshop there was more room and a larger variety of articles could be manufaotured.

Upon leaving the school only a few of the blind were able to supply themselves with books. At the request of the Board of Visitors, the General Assembly appropriated funds in 1849 to give to each child who was graduated or honorable discharged from the sohool one copy of the Bible and a copy of the Declaration of American Independence and the Constitution of the United States of America, "for which no charge shall be made against said graduating or retiring pupil, but shall go and be considered and accounted as an item of the ordinary expenses of the said Institute." I

In accordance with the same act, the sum of $\$ 3,000.00$ was to be appropriated annually for three years "to be applied, in the disoretion of the Board of Visitors, to the payment of the ordinary ourrent expenses of the Institution; to the painting, papering and finishing of the main building; to the procurement of oarpoting for the floors, and of suitable chairs, tables, bods, bedding, windowblinds, and other furniture for the various rooms, passages and apartments thereof; to the purchasing of neoessary books, charts, maps, globes, instruments, apparatus, oto., for the library and literary department of the Institution; to the erection and making of improvements on the lands and grounds appendant and appurtenant thereto, in fencing, building, repairing and decorating." 2

1. Ibid., 1849-1850, p. 45

2. Ibíd., 1849-1850, p. 45 
At the same time, the number of pupils to be sustained as beneficiaries of the State in the Institution was inoreased from forty to sixty. Nr. Patten's repeated trips to each county were oncouraging more and more blind persons to take advantage of the opportunity to secure an education and learn a trade which would enable them to beoome self-supporting after graduation.

In 1850, Miss Georgiana Shaw was added to the faculty of the blind school as a teacher in the work department of the female pupils. "Such a teacher has long been greatly needed in the Institution, and it has been to us a souroe of deep and oonstant regret that we have not felt authorized to amploy one." 1

There were forty-three pupils enrolled in the blind sohool in 1850 -- twenty-four males and nineteen females. All exoept one were residents of Kentuoky; the one excoption, a girl, was sent from st. Louis, Missour1. Up to that time, eighty-one persons had boen received into the Institution. In 1849, the State Auditor had reported some two hundred nineteen "unfortunate human beings who are deprived of vision, and who are doomed to grope in physical darkness, to the full and and term of their respective pilgrimages on earth." 2 This number doubtloss inoluded all blind, and not alone the blind youth of the state who would be eligible for admittance to the Institution.

In 1851, the first, and probably the greatest, calamity came to the Kentucky blind school. On the night of Monday, the 29 th of September, about eight o'clock, fire was disoovered in one of the upper stories of the building. A full account of the catastrophe was given in the local

1. Report of the Kentucky Institution for the Blind, 1850, p. 3

2. Ibid., "Report of the Joint Committee appointed to visit the Institution for the Eduoation of the Blind, In Louisville," 1849, p. 4 
newspapers the following morning:

Owing to its great distance from most of the engine-houses, the fire had made considerable progress before the companies got there, and when they arrived, another difficulty presented itself. There were no cisterns close by and those nearest were soon exhausted of water. Some of the engines had to be used for supplying others with water. The roof and second and third stories were entirely destroyed, and the furniture was either destroyed or so much damaged by water and by being removed as to render it valueless. The unfortunate inmates were all saved. Mr. Patten, the superintendent of the institution, received some injury by a timber falling on him. It is not known how the fire originated. The building was owned by the state. The entire loss cannot fall much short of $\$ 10,000,1$

Two other newspapers, The Louisville Daily Democrat, and The Daily Courier, stated that the loss would be between $\$ 25,000$ and $\$ 30,000$ as the building was not covered by insurance. ${ }^{2}$ However, in reporting the calamity to the General Assembly in his annual report of that year, Mr. Patten stated that the Institution was partially covered by an insurance of $\$ 5,000 \ldots$ "a sum as large as it was practioablo to have insured upon the building. " 3

On the night of the fire, the thirty-five blind pupils were kindly sheltered by friends of the Institution in the neighborhood, and the following day, the trustees of the University of Louisville offered to the school the use of one of their large buildings at Ninth and Chestnut Streets, erected for the collegiate and law dopartments of the university. 4 concerning this action, the following record was made in the Trustee Minute Books, of the University of Louisville, September 30, 1851:

The Institution for the Blind having been destroyed by fire last night, it is ordered by the Board that the Trustees of the Kentucky Institution for the Eduoation of the Blind be permitted to take

1. The Louisville Daily Journal; September 30, 1851 ; Tri-Weekly Kentuoky Yoeman, Frankfort, October 2, 1851

2. The Louisville Daily Demoorat and The Dally Courier, September 30, 1851

3. Report of the Kontucky Institution for the BIind, 1851, p. 5

4. Ibid., 1851, p. p 
possession of the building intended for the academical department. The Trustees for said Kentucky Institution to insure the building for twelve months in the sum of $\$ 10,000$ and to keep and return the house in good order and repair to be delivered to the Trustees of the University upon demand. 1

As a result of this generosity, the operations of the school were hardly interrupted by the calamity whoh laid the building in ruins. Keporting the removal of his sohool to the temporary location, Mr. Patten says:

The university building, with an outlay of about two hundred and fifty or three hundred dollars, affords to the sohool comfortable accommodations for the present. The apparatus, musioal instruments, furniture, etc., destroyed by the fire, were worth some fifteen hundred dollars, and should be immediately replaced. The loss of these is felt more severely at the present time than any other oocasioned by the fire.2

Soon after the blind school had been temporarily removed to the university building, the Board of Visitors sought to obtain another permanent home for the Institution. The destruction of the building on Broadway and the need of more land for the school, caused the trustees to think it proper to sell the ground where the sohool had formerly been located, in order to obtain a more eligible site. For several years, the trustees had been desirous of having land sufficient for exercise grounds, and a garden large enough to furnish the Institution with vegetables. Several generous offers of land were made to the trustees. Two gentlemen, Messrs. E. P. Pope and it. P. Boone offered to donate to the Institution eight acres of land, in West Louisville, "a short distance from this oity, and accessible by a good road, which will soon be improved. The site is on a high and beautiful ridge of land, in a healthy location, on the bank of the Ohio. n3

1. University of Louisville, Trustee Minute Books, 1846-1893, p. 65

2. Report of the Kentucky Institution for the Blind, 1851, p. 6

3. Ibid., 1851-1852, p. 6 
These gentlemen also offered to sell to the Institution two aditional acres for seven hundred and fifty dollars, and to donate two and a half additional aores for a railroad depot. Using the oharter granted to them in 1844, the Board of Visitors hoped to construct, in the future, a railroad which would link the oity of Louisville with the proposed site for the new Institution, and thereby "aid materially in the support of the school."l

Barly in 1852 a committeo from the State Legislature visited the Institution, to inspeot the proposal for selling the Broadway property and the examining of the site in west Louisville, contemplated for the ereotion of the new buildings of the Institution. Authority was granted for the sale of the ground on Broadway, 2 but owing to the objection of some of the legislative comittee, the plans for locating the Institution in West Louisville had to be abandoned. The General Assembly directed the Governor to appoint a committee of three for the purpose of securing ten acres of land, and reporting the same, together with the plans for the proposed buildings to the Governor for his approval. The committee, composed of Messrs. W. Tompkins, Honry Pirtle, and A, M. Jackson, after careful oonsideration, and consultation with the Superintendent and Board of Visitors of the Institution, recommended the purchase of a ten acre tract of land in the eastern section, about a half mile from the limits of the city of Louisville. After a personal inspection of the site by the Governor, Lazarue Powell, the ground, belonging to Frederick G. Edwards, was purchased, in the name of the Commonwealth, by the Board of Visitors, at a cost of $\$ 5,500$, or $\$ 550$ dollars per aore. 3

1. Ibid., 1851-1852, p. 6

2. Aots of the General Assembly of Kentucky, 1852,pp. 357-358

3. Ibid.. 1851-1852, pp. 357-358; Report of the Kentuoky Institution for the Blind, 1851-1852, p. $2 ;$ Journal of the Senate, "Governor's Hessage, $1853-1854, \mathrm{pp} \cdot 17,26$ 
The lot, as originally laid off by the Superintendent, lies in the form of a beautiful parallelogram, 800 feet in length, with a front of $544 \frac{1}{2}$ feet on the Frankfort turnpike road. The site is the highest, most oommanding, and most beautiful in the vicinity of Loulsville. Now Albany, Jeffersonville, Portland, and Louisville, are all spread out like a map before it. The Ohio River winds beautifully in viow for several miles, until it seems, at last, to lose itself among the blue hills of Indiana. The edifice is in full view of the travel on the Ohio River, the Frankfort railroad, the Shelbyville and Bardstown turnpike roads, and several other great avenues leading into the interior of Kentucky.

The site is in a healthy neighborhood, it has a soil of great fertility, is capable of the most perfect drainage at little or no expense - in short, almost all things combine to render it the most desirable location for a State Literary Institution that could be seleoted in the vicinity of Louisville.1

Imediately after the purchase of the ten acre tract, Mr. Patten drew up plans for the construction of the buildings, and presented them to the General Assembly at Frankfort. These plans were approved unanimously and in acoordanoe with an act passed January 7 , 1852, the sum of $\$ 10,000$ was appropriated to commence the ereotion of the new edifice. ${ }^{2}$ In addition to this appropriation, the building fund was also swelled by the sale of the Broadway lot which netted $\$ 12,376.74$; insuranoe collected on the building destroyed by fire added the sum of $\$ 5,025.00$; the sale of old iron netted $\$ 500.00$. After deduoting the $\$ 5,500$ spent in the purchase of the new tract of ten acres, there remained in the building fund a total of $22,401.74$. The amount expended in the building and materials amounted, in 1852 , to the sum of $\$ 22,255.79$, leaving in the building fund, at the close of that year, the sum of $\$ 145.95 .^{3}$

The building comittee soon obtained bids from various contractors and gave the contract to the lowest bidder who could "furnish

1. Report of the Kentucky Institution for the Blind, 1851-1852, p. 2

2. Acts of the General Assembly of Kentucky, 1852, pp. 357-358

3. Report of the Kentuoky Institution for the Blind, 1852-1853, p. 3 
ample seourity for the faithful performance of his engagements." The construction of the present home of the Kentucky blind school was comenced in 1853. In order to secure "constant, faithful and responsible" supervision of the work, the committee called to their assistance Mr. F. Costigan, Esq., "an arohiteot of great experienoe, refined taste, and rare ability." ${ }^{l}$ Mr. Costigan had, in 1847, supervised the construction of the Indiana school for the blind, and the Kentucky school was to be of similar architecture.

In November, 1853, Mr. Otis Patten, a teacher in the sohool since the beginning of its operations, tendered his resignation to the Board of Visitors in order to accept the position of superintendent of the Louisville Orphans' Home. After several other changes had been made, the faoulty, in 1853, was composed of Mr. Bryce Patten, Director; Miss Elizabeth Earle, teacher; Miss Margaret M. Meloher, teacher; Edmund P. Marion, teacher; Joseph B. Smith, teacher of musio; Miss Esther Pergrin, matron; Francis Velad, foreman in the meohanical department; kobert 6 . Hewett, physioian. 2

As of August, 1852, it was calculated that the sum of $\$ 30,000$ would be required in order to put the Kentuoky school for the blind under roof and finish it ready for occupanoy. 3 To meet this need for additional funds, the General Assembly passed an act on February 11, 1854, at the request of the Board of visitors, appropriating $\$ 25,000$ "to enclose the building already commenced, and finish the interior." 4 On the eighth of Ootober, 1855, the new building was ready to receive its occupants. 5

1. Ibid., 1852-1853, p. 13

2. Ibid., 1852-1853, p. 9

3. Journal of the Senate, 1853-1854, p. 29

4. Aots of the General Assembly of Kentucky, 1854, p. 14

5. Report of the Kentucky Institution for the Blind, 1853-1855, p. 5 
CHAPTER IV

YEARS OF EXPANSION, 1855-1930 
On October 8, 1855, after occupying the University of Louisville academio building for five years, the Kentucky Institution for the Bducation of the Blind moved into its new and permenent home on the Shelbyrille turnpike, now Frenkfort Avenue. The main building. modeled after the plan of the Indiana Institution for the Blind at Indianapolis, 1 and designed by the famous architect, Gideon Shryock, who also designed the Court House in Louisville and the Old Capitol at Frankfort, ${ }^{2}$ is a very imposing and impressive structure of Greek Revival style. "All the exterior walls are of plastered brick with stone trim, except the first story of the main building on the south elevation which is of dressed stone, ornamented by a graceful Ionic portico. A large dome on an octagonal base, crowned with a ciroular oupola having eight columns, rises above the main roof of the center portion of the building. A similar cupola rises above the roof of each flanking wing of the main structure. These three domes are visible from many points in the city. ${ }^{3}$

Although the thirty-eight resident pupils of the school were transferred to the new home, the building was not entirely completed. Conoerning the completion of the structure, the Building Committee for the Institution made the following report in December, 1855 :

Only such parts of the building have been completed as are necessary for the accommodation of the pupils at present connected with the Institution. A portion of the lower story has been completed, and the second or principal story is entirely completed, except the water-closets in the wings, and the warm and cold air registers. The floors are laid in the third story, and most of the rooms in the same are fitted up temporarily as

1. Johnston, op. olt., Vol. II, p. 291

2. Louisville Times, November il, 1936

3. Work Projects Administration of the State of Kentucky, Louisville, A Guide to the Falls Cities, pp. 103-104 
dormitories, and are all occupied. The other parts of the house are unfinished, and, of course, must remain so, until the Legislature make an additional appropriation, as the building fund is now entirely exhausted.1

Soon after the removal of the school to the new building, the number of applicants increased greatly and by 1857 there were seventyfive pupils enrolled. This increase was due partly to the attractiveness of the new and spacious building which housed the school, and in part to the free tuition and oare offered to all blind children of the State who were qualified applioants. The latter was made possible by an enactment of the State Legislature, January 7, 1852, which provided that all blind ohildren of Kentucky, regardless of pecuniary circumstances, were to be received by the institution. 2 The reasons for this measure are given in Mr. Patten's report to the Legislature in January, 1856 :

The poor are no longer humiliated by being required to present proof's of their poverty as a pre-requisite to the reception of their children, and the children of the wealthy are admitted, upon the same terms, to the same privileges. All the blind children of Kentucky are admissible as beneficiaries of the state. The only qualifications for admission are unblemished character, suitable age, fair mental capacity, and freedom from of fensive and infectious diseases. Here are no invidious distinctions. side by side, at the same table, with their teachers, and partaking of the same food, sit the children of poverty and the ohildren of opulence, equally blessed in being permitted, by the numificence of the State, to drink at the same fountains of knowledge. 3

The same act which made free to all blind children of the Commonwealth the privileges of the school also extended the age limit to twenty-one years, if the child entered under the age of thirteen. This inoreased enrollment necessitated the frmediate completion of the main building of the school and the erection of some

1. Report of the Kentucky Institution for the Blind, 1855, p. 22

2. Acts of the Generel Assembly of Kentuaky, 1852, p. 358

3. Report of the Kentucky Institution for the Blind, 1854-1855, p. 10 
out-buildings, since the portion in use was beooming overcrowded. For this purpose, the legislature passed an act March 3, 1856 appropriating twenty thousand dollars to the school, "provided, that no other and further sum shall be appropriated to the completion of said buildings." I A provision in the same act increased the annual allowance for the support and education of State pupils in the school from $\$ 120$ to $\$ 140.2$ This was a great benefit to the school, as they could now purohase some necessary apparatus and equipment for their work, i. $\theta_{\bullet}$, organ, pianos, raised maps, globes, artioles of furniture, and a pair of horses and car, the latter needed to convey the children to churches in the city, two miles distant. 3

In addition to the annual allotment of $\$ 140$ per capita, a legislative enactment of February 27, 1865 provided for the annual appropriation of $\$ 6,000$ in order to defray some of the expenses and debts of the institution. By an act of warch 11, 1870 this annual appropriation for the support and maintenance of the blind sohool was inoreased to $\$ 10,000$, and in 1906 the annual appropriation was increased to $\$ 15,000$. From time to time the trustees found it necessary to call upon the Legislature for further appropriations to meet various emergency needs of the school. The following chart will show some of these appropriations and the use to which the money was put:

Date Amount allotted Use of the allotment

Feb. 3, $1858 \$ 7,500$

March 1, $1860 \quad 15,000$
Ereot hoating apparatus, water closets, etc.

To enclose grounds with a fence, orect workshop, purchase organ, paint interior, and finish public hall and sleeping rooms.

1. Acts of the General Assembly of 'Kentuoky, 1855-1856, Vol, I, p. 49

2. Ibid., 1855-1856, Vol. I., p. 49

3. Report of the Kentucky Institution for the Blind, 1854-1855, p. 11 


\begin{tabular}{|c|c|c|}
\hline Date & Amount allotted & Use of the allotment \\
\hline Feb. 20,1868 & $\$ 20,000$ & $\begin{array}{l}\text { Debts, musical instruments, supply } \\
\text { water, fire apparatus, furniture, } \\
\text { otc. }\end{array}$ \\
\hline liarch 11, 1870 & 10,000 & $\begin{array}{l}\text { Debts, repairs and improvements on } \\
\text { bulldings and grounds, water pipe } \\
\text { connection with Louisville Water } \\
\text { Company. }\end{array}$ \\
\hline March 11, 1873 & 10,000 & $\begin{array}{l}\$ 8,000 \text { for heating apparatus; } \\
\$ 1,500 \text { for gas pipes and fixtures } \\
\text { for lighting purposes; } \$ 500 \text { for } \\
\text { models of eye, ear, brain, etc. }\end{array}$ \\
\hline
\end{tabular}

It is interesting to compare the expense of educating a blind person with that of educating a normal person. A Bible for a seeing person could be bought for thirty cents, a Bible in raised letters, printed by the American Bible Society, oost twenty dollars plus two or three dollars transportation charges. A map suitable for any seeing pupil may be purchased for five dollars; the same map when adaptable for the use of the blind cost nearly fifty dollars. An ordinary slate for a seeing person colld be had for a few cents; a good slate prepared for the blind cost ten or twelve dollars. Globes for the blind cost several hundred dollars each. Since the blind must learn some trade in order to earn a living, additional expense was incurred in buying and maintaining the mechanioal tools, materials, workshops, and teachers. 1

Early in 1857, the Board of Visitors leased some eighteen aores of land west of the Institution from W111iam H. Pope, Esq., f'or the purpose of providing the school with a garden, pasture and stables for the cows and horses, fruit orohard, and a suitable place for a workshop for the mechanical department. By this addition of pasture and garden land, the Institution was able to supply the sohool with a

1. Ibid., 1854-1855, p. 15 
sufficient amount of milk and butter, a large variety of vegeatables and such fruits as grapes, strawberries, raspberries, peaches, apples and quinces. ${ }^{1}$ iur. James i. Henning, Esq., took a great interest in this new enterprise of the school and supplied a valuable number of fruit trees, at no cost to the Institution. Lany of the shade and ornamentul trees now standing on the grounds of the Institution were also gifts of Mr. Henning.

In 1861, when the Civil war broke out and the southern portion of Kentucky was invaded by the Confederate forces, the blind pupils who resided in that section did not return to the school. 2 During the Rebellion the enrollment decreased twenty-eight percent. Besides this decrease in enrollment, the Institution was subjected to other trials and tribulations. In 1862, when Louisville was threatened by the Confederate forces under General Bragg, the grounds and buildings of the Institution were occupied by the Federal troops, and the school authorities were forced to abandon their property. Shortly after the Battle of Perryville, in Ootober 1862, the buildings of the Institution were converted into a military hospital, at the instigation of two Louisville doctors, Dr. J.F. Head, Medical director of Louisville, and Dr. M. Goldsmith, his assistant. The Federal authorities under Ceneral Nelson at first refused to sanotion this move. However, the enormous number of oasualties in the Battle of Perryville necessitated the use as a hospital of any suitable building in the vicinity of Louisville. 3 Twenty-four hours were given the sohool for vacating the building. The "Alexander Place," on Workhouse

1. Ibid., 1856-1857, pp. 9-10

2. Ibid.., 1861, p. 4

3. Ibid., 1862 and 1863, p. 5 
Road, now a portion of Cherokee Park, was leased, and those pupils who could not be sent to their homes were removed to this house, "sufficient to accomodate, in tolerable comfort, about twenty of the pupils..." 1

After all the wounded soldiers had been removed, the trustees of the blind school tried fruitlessly to have their buildings restored to them. After continued pleas to the military authorities in Louisville, an appeal to the War Department brought a prompt order for the building to be vacated and restored to the school immediately. However, the medical authorities delayed their abandonment of the buildings for several months. Finally, on January 5, 1863, the doctors and nurses were evioted from the building by the trustees "under an order authorizing them to use a file of soldiers for that purpose... $n^{2}$ The sohool returned to its buildings on March 17, 1863, but was not able to maintain full and complete operation again until June 5, 1863, more than seven months since the occupants had been forced to flee. Sinoe that time the operation of the school in the present building has boen uninterrupted.

During the sohool session of 1866 a new innovation was commenoed at the Kentucky Institution -- the Introduction of the Braille system of point-writing and point-printing. 3 Professor Henry Robym of St. Louis visited the Institution during the sumner of 1866 and gave a few lessons in the Braille system to a small class of pupils. The results were very satisfactory and instruction in Braille was given to all pupils of the sohool in addition to other systems then

1. Johnston, op. cit., Vol. II, p. 291

2. Report of the Kentucky Institution for the Blind, 1862 and 1863, p. 6 3. Ibid., 1866, pp. 6-7 
taught. The following extract is from the report which Professor

Robyn made to the Missouri Legislature oonoerning his Kentucky visit:

Mr. B. M. Patten, Principel of the Kentucky Institution for the Blind, and Trustee of the National Printing House for the Blind, located in Kentucky, visited our Institution in May last, and invited me to give instruotion to some of his pupils in the Braille system. I went there on the 25th of June, and spent two weoks with him, during which time I taught $s i x$ of his pupils. I comenced at an unfarorable time, at the olose of the session, when all pupils are exhausted by study; yet the result achieved, in so short a time, was most astonishing. I taught the olass eight days, and the ninth day was spent in reviewing thedifferent characters, and in examples in different studies; and, to my great astonishment, I must oonfess that my pupils knew, theoretically, every character in reading, arithmetio, and music, as well as I did myself, and nothing remained for them to do but to make practical use of the same, which was not negleoted, as I have received several letters in Braille from them ... It should be understood that the Braille system is not the thorough education of the blind, but that it only facilitates the teacher and the pupil to impart and recoive more easily than by any other system. However, two things are nocessary to produce such results as I witnessed in Kentucky. First, a teacher who is able to teach in a practical way; and second, pupils who have the right spirit and determination to learn. Such I found in those pupils in the Institution in Kentucky. I may say that during my more than twenty-five years' instruction, I never found a whole class so attentive, intelligent, patient, and determined to learn. During all the time I never noticed one of them wayward, or, for an instant, indifferent to their studies. It is plain to see what discipline and good behavior the instructors had brought in the pupils, and easy to ascertain how devoted the teachers were to their profession and their pupils.1

Although Braille was introduced at the Kentucky school as early

as 1866, it was not adopted for use at the school until some time

during the 1920's. There was much confusion among the educators of the blind throughout the country as to the best system of embossed printing for the blind. Three systems of embossed printing -- Boston Line Letter, New York Point, and Braille -- had been developed and introduced in different schools throughout the oountry. For more than a generation there existed a "type fight," but this situation was remedied somewhat in 1918 when all the school for the blind adopted the Braille

1. Ibid., p. 7 
system as the uniform method of printing for the blind of this country. The Kentuaky school, however, still held to the New York Point method as the best system and was one of the last schools to utilize the Braille method of printing. 1 As late as 1922, New York Point was still being taught in the school, although the beginning classes were taught to read and write in Braille only. ${ }^{2}$ For many years the blind have been noted for their exaellent broom-making industry; and this became one of the most popular branches of instruction at the Kentucky school. Upon completion of their course, the pupils could purchase machine for broom-making from the Institution and set up their own factories throughout the State. In connection with this industry, it was soon discovered that no broom-making machines were manufactured for sale in Kentucky. As a consequence, the school was forced by necessity to introduce the manufacture of them in the mechanioal department, thereby oreating another industrial courso in the currioulum. The Board of Visitors reported to the legislature in $1860^{\circ}$ :

The machines made during the last year, being of superior quality, have attracted the attention of broom-makers in different parts of the West, and we have received from Kentucky and other States more orders for machines than we have been able to fill; but we hope to complete arrangements that will enable us to supply the demand with superior machines, manufactured, in part, by the industrious pupils of this institution. 3

In 1869 a similar ciroumstance caused the introduction of another valuable industrial course in the mechanioal department -map-making. For some time the school had felt the need for raised maps and globes, but, due to the fact that such apparatus was enormously

1. 50th Report of the American Printing House, June 30, 1919, pp. 12 and 13; Prooeedings of the 24th Biennial Convention of the American Association of Institutions for the Blind, (Colorado Springs: 1918), pp. 18-20

2. Talk with Wr. Harold Reagan, student in the school during 1922; Interview with Mr. Clifford B. Martin, former superintendent of the blind sohool, 1923-1930.

3. Report of the Kentucky School for the Blind, 1866, p. 9 
expensive and very difficult to obtain in Europe or America, the school was forced to omit the study of physical geography from the curriculum. However, in 1869, the superintendent had the mechanioal department manufacture maps and globes suitable for the use of blind individuals, and "this sohool has now a better supply of superior globes and dissected and wall maps then any other Institution for the blind in the United States."

The first important administrative change in the blind sohool personnel came about in 1870 whon Mr. Patten, who, aside from being superintendent of the school, had also managed the American Printing House for the Blind since its inception in 1858, resigned.2 To fill the vacancy left by Mr. Patten, the Board of Visitors was fortunate in securing as superintendent Mr. Benjamin Bussy Huntoon, long a teacher and resident in Louisville.3 In this capacity Mr. Huntoon served the blind of Kentucky for forty-one years until his. resignation in 1911. He died August 9, 1919.

Probably few other superintendents have contributed as much to the welfare of the blind in this state and throughout the nation as hir. Huntoon. Striving always to operate the blind school in the most efficient and economio manner possible, he proved to be not only an excellent manager of the sohool, but through his untiring and unceasing interest and industry, he became famous as an inventor of innumerable valuable objects for the instruction of blind individuals. In recognition of $\mathrm{Mr}$. Huntoon's derotion to the welfare of the blind, "An kificienoy Study," written by one olosely assooiated with him for

1. Ibid., 1869, p. 6

2. No record is left concerning the cause for Mr. Patten's resignation, nor is any mention made of what became of him after leaving the school.

3. Report of the Kentucky Institution for the Education of the Blind, 
years in the printing house, gives an acoount of just what great

work he has done in the development of printing for the blind.

"Taking charge of a small concern operating a hand power press, printing from movable type, with a book list of less than two pages, developing said printing, keoping it in advance of all improvements, and from a two-room office to a three-story building, electricallyrun machinery, and a book list of ninety-five pages are the achievements of one man. He eliminated movable type by inventing a papiermache process of moulding the type faces and casting the same in a flask invented for that sole purpose. Following out the idea he further cheapened the process by forcing the type faces of the cast stereotype plate into a brass plate .006 inch thick and filling the holes with a suitable filling devised by him. These plates were superseded later by an entire tin plate which Mr. Huntoon invented casting them from the same flasks as the stereotype metal plates were cast. These plates remained until a machine was devised to stereotype the letters directly to a heavy brass plate. Mr. Huntoon secured several of these machines and after putting on a friction block made them practical for our use.

No action was ever undertaken by $\mathrm{Mr}$. Huntoon that did not bear directly on the efficiency of operation and reduction of oost of output.

inr. Huntoon devised and mede the drawings for the first (and the only one for twenty-seven years) cylinder embossing press ever used in the whole world. It was built by a firm of press builders in Chicago, from $\mathrm{r}$. Huntoon's drawings.

He devised boards to enable a blind person to keep the line when writing soript.

He devised a raised soript letter for training the mental sight of the blind, and further a sunken script board that a blind person uses to trace the formation of letters both small and capital.

He made the only effective maps that were ever used by the blind, both solid and dissected to the number of several hundred.

He made the plates for maps out of press board for every State of the United States, and of every country in both hemispheres, having them printed, and bound in atlas form.

He was the cause of printing Geometry, Trigonometry, Algebra, Astronomy, Goography, with diagrams, and all higher branches of educational works, having personally proofread them all.

"Improvement" was the watchword. "Keep at the head of the procession!" the shibboleth.

He went into the bindery, and by actual computation reduced the effective time on five hundred books two weeks, by eliminating all unnecessary motion. Through a crude apparatus that he caused to be 
made, can be out all the muslin used by the American Printing House for the Blind during a year, in half a day, taking previously about a month.

He devised and had made fireproof shelving of pipework and steel bars, which is used in the fireproof vault.

He derised and had made a special tank and drainboard for wetting paper before printing.

He devised a peculiar steam box for use in making the writing boards and script boards mentioned above.

He installed a wire sewing machine that materially reduced the cost of sewing, at the same time devising a cloth-lined guard that permitted the use of said machine.

He installed a drying room that permitted the quicker and better drying of paper.

Following his never-ending campaign of efficiency, after a number of experiments, he devised an original method of printing on both sides of a sheet of paper, with one impression, using the press without alteration, that he had invented thrity-one years before. The plate is locked on the press in the same manner as the single side plate, the printing being done by the rubber forcing the paper into the intaglio or the reverse side, and on the near or cameo side the peper is forced into the rubber, so that the efficiency of a sheet of paper is incieased one hundredfold, there being as much matter on one side as on the other.

When one thinks of a hand press with a possible output of ten or twelve per minute to a power output of eighteen on the ancient press per minute, inoreased to one hundred and twenty per minute by the single side process, to an output of two hundred and forty per minute or fourteen thousand four hundred and sixty per hour by the two side process, "it is to take one's hat off" to the master mind that made it possible. Still further: $\mathrm{Mr}$. Huntoon caused to be made a device that inoreased the efficiency of the plate making machines five hundred per cent, and during many years he was editor of the Sunday School Weokly, which was wholly a labor of love.1

During Mr. Huntoon's long administration the buildings and equipment of the blind sohool were improved and the school broadened and developed along every line. Realizing the need for providing some Instructive and educational program for the blind colored children of the Commonwerlth, from whom he received numerous applioations, Mr.

1. Report of the Kentucky Sohool for the Blind, 1919, pp. 24-27 
Huntoon was successful in March, 1884 in securing from the General Assembly an appropriation of $\$ 20,000$ for the purpose of purchasing eight acres of land adjoining the property of the blind school on Frankfort Avenue and erecting thereon a building suitable for the education of blind negroes. ${ }^{2}$ The building was completed in september, 1886, and was formally opened on October 2 of that year. 2 In 1910 an addition was made to enlarge the building at a cost of $\$ 18,0000^{3}$ Operating under the same management as the school for white blind children, the colored department has its own state appropriation of $\$ 7,000$ annually, and its own staff of seven persons, including the principal and three teachers. While the enrollment of the oolored department has seldom been large (the maximum number of enrollees for any one year being thirty-one in 1908), the present enrollment is eighteen.

Through his economical management, Mr. Huntoon was able to save enough money to erect two new wings to the original building in 1895; hardwood floors, steam heat, gas and electricity were installed and in 1906 the drainage system of the institution was connected with the public sewerage system of the city of Louisvillo.4

It was during the administration of $\mathrm{Mr}$. Huntoon that the blind school sustained two great losses in the deaths of Mr. William Fontaine Bullook, the founder of the sohool, on August 8, 1889 at the age of eighty-three, and of Dr. Theodore Stout Bell in 1885, nember of the Board of Visitors for forty-three years and for twenty-one years president of that body. These two gentlemen gave unceasingly

1. Acts of the Gehoral Assembly of Kentucky, 1885-1886, p. 96

2. Eeport of the Kentuaky Sohool for the BIind, 1886, p. 9

3. Acts of the General Assembly of Kentuoky, 1910, p. 275

4. Report of the Kentucky Sohool for the BIind, 1906, p. 14 
their tine and efforts gratuitously to the welfare of the blind throughout the Conmonwealth and left a living memorial in the work that has been accomplished as a result of their service and philanthropy. ${ }^{1}$

Upon the resignation of Mr. Huntoon on August 20, 1912, Miss Susan B. Merwin, for several years a teacher in the blind school, became superintendent. ${ }^{2}$ To her is given the credit of initiating Boy Scout Troop No. 10, the first troop to be organized for blind boys in the nation. ${ }^{3}$ In 1918 the first Junior Red Cross of the city was organized by the pupils of the blind school and theirs was the first check sent to the local organization in payment of dues. 4 During her administration, in 1914, the General Assembly reduced the Board of Visitors from nine to five nombers and required that the superintendent of the blind school must thereafter be a trained teacher of the blind. 5

In 1916 the Legislature passed an act changing the name from the "Kentucky Institution for the Education of the Blind" to "Kentucky School for the Blind," under which title it operates today." Besides these, the school at one time operated under still another name -the "Kentucky Asylum for the Education of the Blind." 7 The branding of the school as an asylum in 1873 oqused immediate dissention among the authorities of the Institution. They contended that such a name misconstrued the nature and purposes of the school, that it was never

1. Report of the Kentuaky Institution for the Blind, 1889, p. 17;

. 1885, p. $7 \ldots$

2. Ibid., 1912, p. 17

3. Ibid., 1912, p. 18

4. Ibid., 1918, p. 21

5. Ibid., 1914, p. 21

6. Ibid., 1916, p. 9

7. Ibid.., $1882, \mathrm{p} \cdot 34$ 
intended as an asylum for the pauper blind nor a hospital for the treatment of diseased eyes. An interesting incident is recorded in the Annual Report of the school for the year 1885 concerning the efforts of Dr. Bell to correct this misnomer, while he wes president of the Board of Trustees:

A certain contractor who had done work for the Institution and whose account had been presented and approved by the Board, applied to the Secretary for the warrant upon the Treasurer for his money on the morning after the meeting. The warrant lacked the signature of the President, but as the contractor wished to draw his money before banking hours were over, he was given the warrant and direotions for finding Dr. Bell. Arriving at his office, he found Dr. Bell within, and asked him:

"Are you the President of the Blind Asylum?"

"No sir," replied the Doctor very gruffly.

"They told me at the Blind Asylum itself", that you was."

"You have been misinformed, sir. I don't know of any such establishment in the oity."

"It's out on the Shelbyville Pike, sir; and I saw the Blind Asylum myself"."

"You didn't see any asylum at all. You saw the Kentucky School for the Blind, but there is no asylum for blind children in the United States," and after giving this lesson he signed the warrant. I

The nome "Kentucky Asylum for the Eduoation of the Blind" Iived for three years only, 2 after which time the former title was restored. However, as a result of this misnomer, the blind school is often referred to today as the "Blind Asylum."

In 1918 the State Legislature made it possible to extend the scope and work of the Kentuoky School for the Blind to include the teaching of adults, by appropriating $\$ 14,000$ to begin the establishment of a permanent auxiliary department to be known as the Kentucky Workshop for the Adult Blind, under the same management but separate and apart from the sohool, with special appropriations for its maintenance. This department had been established in March, 1913, by

1. Report of the Kentucky Institution for the Blind, 1885, p. 9

2. See titles of Reports of the Kentucky Institution for the Blind, 1873 , 1874, and 1875 . 
Mr. C. B. Martin, a teacher of plano tuning in the blind school. He rented a room in the building then occupied as Reading Rooms in the James Lee Memorial Presbyterian Church on the northeast corner of Frankfort Avenue and William Street where two blind men were employed to make mops. When it became evident that more room was needed, an old frame bouse at 2211 Frankfort Avenue, formerly the Clifton Post Office, was rented in November 1913. Here work was carried on under more farorable conditions and broom-making was introduced. 1

In October, 1916, the shop was moved to 2101 Frankfort Arenue, and in October, 1917, the two adjoining cottages at 2105 and 2109 Frankfort Avenue were rented, the first one to be used for storage, and the seoond for sleeping quarters for the men who lived out of the city and were brought there to learn the trade.2

Up to this time the shop had been maintained by contributions from friends and various organizations and by the sales of mops and brooms. However, it became necessary to ask for State assistance in carrying on this project. A committee from the Legislature visited the shop and pledged its support to obtain financial aid from the State. Accordingly, in April, 1918, the aforementioned appropriation of 14,000 was made available, at which time the workshop became the property of the state, and the equipment and stock on hand, valued at $\$ 2,000$, was given over. Then work on a much more extensive scale was started. 3

On October 11, 1918, the "Clifton Picture Show" building at 2005 Frankfort Avenue was rented. A few months later a retall store

1. Report of the Kentucky School for the Blind, 1927, p. 118

2. Ibid., p. II8

3. Ibid. p. 118 
was opened in the building next door at 2003 Frankfort Arenue. On January 17, 1921, the old building adjoining on the east at 2007 Frankfort Avenue was purchased and on February 3, 1921, the entire property, inoluding the corner bullding, was purchased. The Kentuoky Workshop for the adult Blind then owned the buildings and grount at 2001,2003, 2005, and 2007 Frankfort Avenue. I

On September 27, 1919, a department for women was opened at the Kentucky Forkshop for the Blind, which formerly had instructed only men. The women learn plain sewing, such as hemming, then crocheting and tatting, to be followed by types of more advanced s ewing. 2

In order to make possible the construction of a new workshop, the old building at 2007 Frankfort Avenue was razed. The new twostory fireproof structure, costing $\$ 45,000$, furnished with the very latest machines for mattress work and rug making, was opened June 1 , 1925.3 The workshop receives an annual appropriation of $\$ 14,000$ from the State and together with the proceeds from the sale of manufactured products, is able to maintain a valuable branch of vocational education for the adult blind of the Commonwealth.

The purpose of the workshop is to equip men and women with trades and then allow them to return to their home towns to set up in business for themselves. In an artiole which appeared in the Louisville Herald Post, August 31, 1924, cases were cited where definite benefits were derived from the instruction given at the workshop.

Not long ago four blind men, three colored and one white, were taken out of the poorhouse, where they were a drag on sooiety and burden to themselves, and taught how to become self-sustaining.

1. Ibid., p. 119

2. Louisville Times, September 27, 1919; Louisville Herald, September 30, 1919

3. Keport of the Kentucky Sohool for the Blind, 1927, p. 119 
Another blind man, from the mountain section of Kentucky, despondent because of his helplessness, was trained here. He returned to his native town and estabilished a mop and broom business so large that he was forood to employ four assistants, men who could see. Another blind man from the Bluegrass, after being trained here, returned home and is now supporting not only himself but his aged father and mother and an invalid sister.

On July 1, 1918, the soope of the work of the blind school was further broadened when a home teacher, or field worker, was engaged, whose duty it became to visit the homes of blind adults throughout the State and teach them to read, write, sew and knit. In recent years, when it was found that the learning of Braille was too difficult for some blind adults, the Talking Book Machine, made by the American Printing House for the Blind (see Chapter V), was introduced. Much pleasure and entertainment, as well as instruotive information has been afforded the adult blind by the use of these machines. The plan for their distribution was made possible through the Emergency Relief Appropriation Act of 1935, the Library of Congress acting as sponsor. Throughout the Commonwealth one hundred and five of these machines have been loaned to blind men and women. Records for these Talking Books are obtained from the nearest distributing library and sent to the blind reader through the mail free of cost. The machine resembles a portable victrola and the records are the disc type.' Aside from teaching reading, writing, sewing and kniting, the home teacher also shows the blind adult how to improve his home conditions. Many of them have been encouraged to return to. their former occupations. One blind man was taught how to wind armatures and since that time has been employed in a large electric plant; others were induced to come to the Louisville workshop where they have been taught trades which help to make them self-supporting.

1. Report of the Kentucky School for the Blind, 1936, p. 9 
After a comparatively short administration, Miss Merwin's career at the blind school came to an abrupt end on May 6, 1923, when, at the age of forty-eight, whe died of pneumonia. ${ }^{1}$ Joining the staff of the school in 1895 as a teacher, and becoming superintendent in 1912, Hiss Merwin was always well liked and admired by her pupils. To her memory they donated the two bronze lamps which now adorn the front entrance to the main building of the sohool. 2 In her w111, Miss Merwin left approximately $\$ 11,500$ to the school and printing house for a memorial fund. To the school she also left her library. 3

Upon the death of Miss Merwin, Mr. Clifford B. Martin, assistant superintendent, succeeded to the office of superintendent of the blind school.4 He had been conneoted with the institution during the greater part of his life (since 1885), having been a student, teacher of piano tuning, director and manager of the Kentucky Workshop for the Adult Blind, and since 1912 assistant superintendent of the school. His is the distinction of being the first and only blind superintendent of the school.

It was at the beginning of his administration that the supervision of the blind school and the American Printing House were separated. Prior to this separation, the superintendent of the school was also superintendent and general manager of the printing house. To assume the duties and responsibilities as manager of the printing house, Dr. E. E. Bramlette of the Texas school for the blind, at Austin, was employed.5 Since that day, November 1, 1923, the two institutions have been entirely separate and apart from one another.

1. Louisville Times, Hey 7, 1923; Louisville Post, May 7, 1923

2. Louisville Herald, November 22, 1924

3. Louisville Times, May 14, 1923

4. Louisville Herald, June 6, 1923; Courier-Journal, May 10, 1923

5. Courier-Journal, November $27,192 \overline{3}$ 
Early in Mr. Martin's administration, the General Assembly of Kentucky appropriated $\$ 35,000$ to erect and equip a building to contain the heating plant and laundry for the white and colored departments. I The need for this improvement had been obvious for many years, as the heating apparatus, housed in the basement of the main building, was badly in need of repair. In case any trouble should develop in the boilers, there might result an explosion which would destroy the entire building.

For several yoars Mr. Martin was interested in establishing a farm for the blind youth of the states for this purpose he purchased a farm in Jefferson 6ounty, near Middletown, Kentucky. The boys were to construct their own oottages and would raise the food necessary for their maintenance over the sumer. ${ }^{2}$ Thinking that the State, in due time, would make appropriations for the maintenance of this work, as it had in the case of the workshop, Mr. Martin supported the farm out of his own finances. However, the State failed to recognize the value of such a project and no appropriations were forthcoming.

After forty-five years' association with the blind school and for seven years its superintendent, Mr. Martin resigned in June, 1930,3 and retired to his farm near Middletown, on Blankenbaker Road at Ellingsworth Lane, where today he and Mrs. Martin operate the Kentucky Farm fior The Blind, an institution "for the education and individual training of the blind." Here adults and children not

1. Acts of the General As sembly of Kentuoky, 1924, pp. 31-32

2. Courier-Journal, Fobruary 27, 1927

3. Afull account of the difficulties which arose between the State authorities and Mir. Martin, the superintendent, which oulminated in the latter's resignation, appears in the Courier-Journal, June 13. 1930. The state accused the superintendent of allowing attendance to decrease almost ifty percent, thereby increasing the per capita cost of maintaining the blind students by several hundred dollars. 
attending the State school are given a home and trained to get the best out of their terrible physioal handicap.

Since June, 1930, the Kentucky School for the Blind has been under the supervision of Miss Catherine T. Moriarty, former stenographer, bookkeeper, and teacher of typing at the school. 1

1. The history of the blind school since June, 1930, has been omitted, since insufficient material concerning the development of the school in recent years was available for the use of the author. 


\section{CHAPTER V}

AMERICAN PRINTING HOUSE FOR THE BLIND

$1856-1942$ 


\section{CHAPTER V}

The American Printing House for the Blind, the oldest and largest of its kind in the country, had its origin and inception in the printing department of the Kentucky Institution for the Education of the Blind, now the Kentucky School for the Blind. I Since appropriate books for the use of the blind were very scarce and often unobtainable, each blind school in the country undertook to develop its own printing department and endeavored to emboss the books and manufacture the appliances necessary for the instruction of its pupils. The Kentucky school developed one of the better school printing departments and began to supply copies of its publications to neighboring schools at cost. This arrangement proved so satisfactory that a group of educators of the blind conoeived the idea of a central printing house which would supply books and apparatus for all the schools for the blind throughout the country.

In $1856 \mathrm{Mr}$. D. Sherrod, a blind gentleman of Mississippi, led the movement by securing appropriations from the Legislature of Mississippi and considerable donations from private citizens to establish a national house to print books in raised letters for the blind.2 The charter granted by the State of Mississippi provided that the house should be located in Louisville, Kentucky. Mr. Sherrod next succeeded in procuring the incorporation in Kentucky of a board of trustees to establish the printing house. Soon thereafter, Mr. Sherrod or one of his agents visited the legislatures of each of the States in order to solioit donations and appropriations and to procure the incorporation of a Board of Trustees in each State. ${ }^{3}$ As a result of these early

1. It is for this reason that the chapter on the printing house is being included in this history of the Kentucky School for the Blind.

2. Report of the Kentucky Institution for the Blind, 1866-1857, pp. 7-8

3. Ibid., $\mathrm{pp}$. 7-8 
efforts, the American Printing House for the Blind was chartered by the General Assembly of Kentuoky on January 23, 1858.1

With only meagre funds for 1ts support, the Printing House began its existence as a national, non-profit, private and independent agency for the blind in the printing departmont of the Kentucky school, where for fifteen years it was granted free space for carrying out its operations. After the Civil war it became apparent that the Printing House could not depend upon public donations and grants from the cooperating states to support its progress of publishing books for the blind. During this period there developed intense agitation on behalf of the blind for Federal subsidization of the Printing House, which finally culminated in the Act of Congress of March 3, 1879, whereby the sum of two hundred and fifty thousand dollars, out of the money in the United States Treasury not otherwise appropriated, be, and hereby is, set apart as a perpetual fund for the purpose of aiding the education of the blind in the United States of America, through the American Printing House for the Blind." 2 This sum was to be invested in United States interest-bearing bonds, "bearing interest at four per centum," and the interest to be paid semi-annually to the Printing House. This provided an annual subsidy of $\$ 10,000$. The act further stipulated that the money was not to be expended in the erection or leasing of buildings, but "shall be expended by the trustees of the American Printing House each year in manufaoturing and furnishing embodded books for the blind and tangible apparatus for their instruction...."3

1. Aots of Legislation Affecting the American Printing House for the Blind, (Louisville, Ky, American Printing House for the Blind, I934), pp. 9-10; Acts of the General Assembly of Kentucky, 1857-1858, p. 192

2. United States Statutes at Large, 45th Congress, 1879, Session III, Chapter 186, p. 467; Acts of Legislation Affecting the APH, 1934, p. 15

3. Ibid., pp. 15-16 
Year by year the work of the American Printing House expanded as more blind sohools throughout the country were established. The board of trustees felt the need of establishing a plant, separate from the printing department of the blind school, which would provide more adequate room and equipment to meet the increasing demand for instructive printed material. On Maroh 22, 1882, an act was passed by the General Assembly of Kentucky authorizing the trustees of the Printing House to "erect a suitable building for the purposes of said printing house on the grounds now oocupied by the Kentucky Institution for the Education of the Blind, or to buy a suitable lot for the same purpose in the city of Louisville." 1 All expenses accrued in the erection and furnishing of the Printing House were to be assumed by the Commonwealth of Kentucky. Accordingly, the present site of six and four-fifths acres of land adjoining that of the blind school was purchased and the main portion of the present building was oreoted in 1883. The building, located at 1839 Frankfort Avenue, is constructed of brick and conorete and has 26,000 square feet of floor space on its three floors and full basement. Until recently, all the work of the Printing House was done in this building. However, today, becaluse of its enlarged program, the main building houses the administrative offices, the Talking Book department, the Braille stereotypong and proofreading department, and all of the stocks of embossed plates and completed materials such as bound Braille books, Talking Book records, and appliances, which are held as a sort of depository against the future needs of the schools. 2

1. Acts of the General Assembly of Kentucky, 1881-1882, Vol. I, p. 47

2. Interview with Mr. A. C. Elis, Superintendent of the American Printing House for the Blind. 
When the Frankfort Avenue building became inadequate to house the current program of activities of the Printing House, a small factory building was rented in downtown Louisville in order to help solve this problem. The building, looated at 825 West Broadway, provides an additional 11,000 square feet of floor space, and houses the Braille printery and bindery, together with the shops for the manufacture of tangible apparatus. The rent for this auxiliary plant is paid out of funds other than the Federal Government appropriation. ${ }^{1}$ While these two buildings serve the needs of the Printing House at present, nevertheless the Trustees have planned an enlarged plant which will consist of the present main building remodled and a modern factory-type building erected at the rear of the present plant. This building improvement would add approximately 30,000 square feet of floor space to the present plant and would provide ample and adequate space not only for the current needs of the institution but also for those of years to come. It is estimated that such an improvement would cost approximately $\$ 100,000$ in normal times. 2

The American Printing House for the Blind is governed by a Board of Trustees consisting of an Exeoutive Committee of seven Kentucky citizens and ex-officio the superintendents of all the public institutions for the eduoation of the blind in the United States, the territories and the District of Columbia. ${ }^{3}$ The members of the first Board of Trustees were: James Guthrie, William F. Bullock, Theodore S. Bell, Bryce M. Patten, William Kendrick, John G. Barrett, and A. C. Brannin.

1. Ibid.

2. Ibid.,

3. Aats of the General Assembly of Kentucky, 1857-1858, Vol. I, p. 193;

- United States Statutes at Large, 45th Congress, 1879; Acts of the General As sembly of Kentucky, I879-1880, p. 286 
A superintendent, elected biennially by the Board of Trustees, acts as supervisor, administrator and general manager of the institution. For many years the superintendent of the Printing House was also superintendent of the Kentucky School for the Blind. However, with the death of Miss Merwin in 1923, the administration of the two institutions was separated and Dr. E. E. Bramlette of Texas, formerly superintendent of the school for the blind at Austin, assumed the superintendency of. the Printing House. ${ }^{l}$ When, in March 1829, Dr. Bramlette died of a heart attack, his position was filled by Mr. A. C. Ellis, also former superintendent of the Texas sohool for the blind, the present superintendent of the Amerioan Printing House for the Blind.2

A Committee on Publications, composed of five Trustees, is elected every two years by the Board of Trustees. It is their duty to select each year from the recommendations of the superintendents of the various blind sohools throughout the country the books to be printed under the Government appropriation. 3 It is also the privilege of the superintendent of any blind school to authorize the expenditure of all or any part of the Federal quota allotment of his school, as provided in the Act of 1879 , to the publication of any title or the manufacture of any tangible apparatus selected by him for use in his school. 4

During the first twenty years of its existence, the budget and personnel of the Printing House were very small. The total annual expenditures seldom exceeded $\$ 10,000$ and there were never more than six

1. Courier-Journal, Novernber 23, 1923

2. Herald-Post, Harch 6, 1929

3. Acts of the General issembly of Kentucky, 1857-1858, Vol. I, p. 193; Aots of Legis lation Af'ecting the APH, p. 2 and p. 8

4. Ibid., p. 8 
or eight full-time employees. The expenditures increased to $\$ 20,000$ following the passage of the Act of 1879 and the erection of the new building in $1883 .^{1}$ By 1920 the staff had increased to twenty persons and the budget amounted to $\$ 38,461.50 .^{2}$ According to the latest available report, the total operating disbursements for the year 1940-1941 were $\$ 321,379.54 .^{3}$ In the past fifteen years, the number of employees has increased from thirty-five persons to approximately one hundred twenty $\cdot^{4}$

The increased expansion of the work of the Printing House necessitated increased appropriations from the Government. On August 4, 1919, an act was passed by the 66th Congress adding $\$ 40,000$ annually to the original appropriation of $\$ 10,000$ in 1879.5 In February, 1927, the annual appropriation was increased to $\$ 75,000,6$ and in March, 1937 , an act was passed by the 75 th Congress granting the present appropriation of $\$ 125,000$ annually for the needs of the Printing House. 7

In addition to the government appropriation, the receipts of the Printing bouse also include sales of publications and apparatus to other then public institutions, misoellaneous sales and refunds, Readers' Digest Fund, Building Fund, and bank notes. In 1941 the annual receipts from these sources totaled $\$ 354,196.54 .^{8}$

The functions of the Frinting House are many and varied. Originating as a plant wich printed embossed books and manufactured tangible apparatus for the instruction of the blind, the institution has increased

1. 16th Report of the American Printing House, 1883, p. 3

2. 52nd keport of the American Printing House, 1920, pp. 5-10

3. T3rd Report of the American Printing House, 1941, p. 29

4. Interviow with Kr. A. C. Ellis, Superintendent of Printing House.

5. Acts Affecting the APH, p. 17; United States Statutes At Large, 66th Congress, 1919, Session 1, Fart 1, Ch. 31, p. 272

6. Ibid., 69th Congress, 1927, Session II, Part 2, Ch. 76, p. 1060.

7. Ibid., 75th Congress, 1937, Session I, Part I, Ch. 736, p. 744

8. 73rd Report of the American Printing Fouse, p. 29 
the scope of its functions to include printing in Braille of books and magazines for schools, for organizations which provide free literature for the blind. For the thousands of prople who cannot read Braille, the Printing House manufactures the "Talking Book," long-playing phonograph records recorded solely for the use of the blind and reproduced on a highly specialized phonograph. Today the Talking Book department is a major activity of the institution. Huch additional original material for the instruction of the blind is designed and manufactured in the plant. These are: special printing presses, embossing maohines, sectional maps, Braille writing frames, a Braillewriter, arithmetic slates, peg boards for kindergarten, frames for writing longhand, and sentenoe boards. Aside from the manufacture of apparatus for publio use, the Printing House also manufactures most of its own machinery, since there is none otherwise manufactured. ${ }^{l}$

The American Printing House for the Blind cooperates to the fullest extent with all agencies and organizations which are connected in any way with the welfare of the blind. Besides being the official schoolbook printery for the whole country, it prints books and periodicals for organizations which provide free literature for the blind. The most important project in this phase of the Printing House's services is the execution of contraots for the manufacture of Braille and Talking Books to the order of the Library of Congress, "Books for the Adult Blind." In accordance with the Pratt-Smoot Law, pessed in 1930, $\$ 350,000$ is appropriated annually to the Library of Congress for the purchase of Braille and Talking Books to be supplied to designated free regional circulating libraries for the blind. 2

1. Ibid., p. 7

2. Interview with ir. A. C. Ellis, Superintendent of the Printing House. 
The facilities of the Printing House are also made available to other agencies than the Library of Congress. For nearly fifty years the American Bible Society has been distributing free of charge, or for a nominal sum, Braille editions of the Bible to blind individuals. These Bibles are printed at the American Frinting House for the Blind.

The third largest project of the Printing House is the production and distribution of both Braille and Talking Book editions of the Readers' Digest. This work was undertaken in 1928 as a means of bringing to blind persons a knowledge of current affairs. The Readers' Digest Association, Pleasantville, New York, permits the free use of its oopyrighted materials by the Printing House. This project has now grown to such proportions that approximately thirty-two hundred copies of the three-part Braille edition and three hundred twenty-five sets of the ten-record Talking Book edition are produced and distributed freo each month - a yearly budget of a pproximately $\$ 45,000 .^{2}$ The expenses accrued in such a project are paid almost entirely through public donations.

The scope of the Printing House's services increases year by year as new projects are designed and carried out by the institution. The greatest problem at the present time is the necessity of providing a more adequate building to house all the activities of the plant under one management. However, with the development of the present Defense Program, and the adoption of the plan of priorities for many essential materials, the construction of a new Printing House must be deferred for the duration of the war.

1. Interview with $\mathbb{M r}$. A. C. Ellis, Superintendent of the Printing House. 2. Ibid. 
CHAPTER VI

CONCLUS ION 
In concluding this history of the Kentuoky School for the Blind, it is well to sumarize some of the outstanding features of its development. Having been one of the earliest States to adopt a program of education and instruction for those handicapped by blinaness, Kentuoky now has an institution of which it may well bo proud. Originating in a one-room cottage, supported by public subscriptions and the well-wishes of the public, the Kentucky School for the Blind has grown to an Institution comprising a plant of several buildings, and supported by a State appropriation of $\$ 68,500$ per annum. With only five students enrolled during the opening days in 1842. the enroliment has increased to the present number of one hundred sixty-five children coming from fifty-eight oounties in the State. The staff of the school has increased from a superintendent, matron, and two teachers in 1842, to the the present number of fortynine, fourteen of whom are teachers.

In the course of its development and progress, the functions of the blind school have inoreased in scope to include the instruction of blind ohildren from kindergarten through high school, free of any expense; in addition, since 1884, the sohool has maintained a colored department which has an enrollment of sixteon pupils, a staff of seven persons, including three teachers, and an annual State appropriation of 7,000. The Kentucky Workshop for the Adult Blind, established in 1913, has aided many adult blind to become self-supporting through its program of industrial training. In the Kentucky school was born the American Printing House for the Blind, a national institution which, by means of Federal appropriations, prints reading material for the blind throughout the nation and manufactures a variety of tangible apparatus espeoially 
adapted to their use.

From its inception in 1842 until 1930, the Kentuciky Sohool for the Blind was under the leadership of only four superintendents, each keenly interested in his work and contributing materially to the welfare of blind persons in this Commonwealth, and indirectly to the welfare of the blind throughout the nation.

Although there is no national rating of blind schools throughout the country, it is the opinion of this writer that the Kentucky school does not rank among the most outstanding institutions for the education of the blind youth of America. Nevertheless, it must be conceded that the Kentuoky School for the Blind is aiding materially in meeting a very urgent and necessary need among the physically handicapped of this Stato. 
APPENDIX 


\section{THE KENTUCKY INSTITUTION FOR THE EDUCATION OF THE BLIND}

WHEREAS the system of Common Schools is intended for the benefit of all the children in the Commonwealth of Kentucky, and a fund has been set apart for that purpose; and, whereas, it is the duty of the State to promote the education of the blind, and experience having demonstrated that this desirable object can be effected by a judioious and well adapted course of eduoation -- therefore,

Sec. 1. BE IT ENACTED BY THE GENERAL ASSEMBLY OF THE COMMONWEALTH OF KENTUCKY, That there shall be established, in the City of Louisville, an institution to be called "the Kentucky Institution for the Education of the Blind," which shall be under the government of seven Visitors, to be appointed annually by the Board of Education, who shall notify them of their appointment, and prescribe a day for their first meeting, or, in the event of failure, for a subsequent one. The said Visitors, or a majority, shall appoint, from their own body, a President to preside at their meetings, and a secretary to record, attest and preserve their proceedings. The said Visitors shall be, and they are hereby, authorized and empowered to receive, by legacies, conveyances, or otherwise, lands, slaves, money, and other property, and the same to retain, use and apply to the education of the bind within this Cormonwealth, to any emount, the interest, profits or prooeeds of which shall not exceed the sum of thirty thousand dollars per annum. The said Visitors shall be charged with the ereotion, preservation, and repairs of the buildings, the care of the grounds, and of the interests of the institution generally. They shall have power to employ all necessary agents; to appoint and remove Professors (two-thirds of the whole number concurring in every case of removal); to fix their compensation, prescribe their duties, and the course of education; to ostablish rules for the gorernment and discipline of the pupils; to regulate tuition fees; to prescribe and control the duties and proceedings of all persons with respect to the property and interests of the institution; to draw from the Common School fund, or the Treasury, in the manner hereinafter prescribed, such moneys as are, or shall be, charged by law on either, for the benefit and support of said institution; and, in general, to direct and do all matters and things, which, not being inconsistent with the constitution and laws of the United States, or of this State, shall seem to them most expedient for promoting the purposes, and fulfiling the objects of said institution; which several functions they shall be free to exercise in the form of by-laws, rules, resolutions, orders, instructions, or otherwise, as they may deem proper. The sald Visitors shall have such stated and occasional meetings as they shall themselves prescribe. A majority shall constitute a quorum for business; and all vacancies occurring by death, resignation, removal from the Commonwealth, or failure to act for the space of three months, shall be supplied by the appointing power. The President and Visitors shall be, and they are hereby declared, a body corporate, under the style and title of "the President and Visitors of the Kentucky Institution for the Education of the Blindk" with the right, as such, to use a common seal, to plead and be impleaded in all courts of justice, and in all cases in 
which the interests of the institution are involved. The institution, hereby established, shall, in all things and at all time, be subject to the control of the Legislature; and it shall be the duty of the Bourd of Visitors, annually, to make a report to the Board of Education, (to be laid before the General Assembly), which shall embrace a full account of the receipts and disbursements, the funds on hand, and a general statement of the condition of said institution. There shall, also, be a comittee of twelve ladies, selected by the Board of Visitors at their first meeting, and their vacancies filled, from time to time, as they may happen from death, removal, or resignation, to aid in the managenent of the institution, under such provisions as may, from time to time, be prescribed by the by-laws. Indigent children, resident any where within the state, shall be received into the institution, maintained and educated gratuitously, as far as the funds of the institution will admit: PROVIDED, that when more children are of fered for the benefit of this institution, than can be received at any one time, the Visitors shall so apportion their number among the several counties of this comonwealth, according to their representation, when aplication shall be made, that every county may equally receive the benefit of the same.

Seo. 2. BE IT FURTHER ENACTED, That there shall be, and is hereby, appropriated, out of the revenue of the Common School Fund, which has heretofore accrued, or which may hereaf'ter accrue, from the dividends on bank stock held by the Board of Education, the sum of ten thousand dollars, which shall be drawn for the Board of Education, as the dividends on the said bank stock may be declared, and by them paid to the Board of Visitors when demanded, in the manner, and under the regulations provided for in the act, entitled, "an act to establish a system of Common Sohools in the State of Kentucky: "PROVIDED, that no portion of this endowment shall be paid until this institution goes into actual operation. 1

Approved, February 5, 1842

1. Acts of the General Assembly of Kentucky, 1842, pp. 26-28 
The following is a list of those who have hald office in the Board of Visitors since the foundation of the institution:

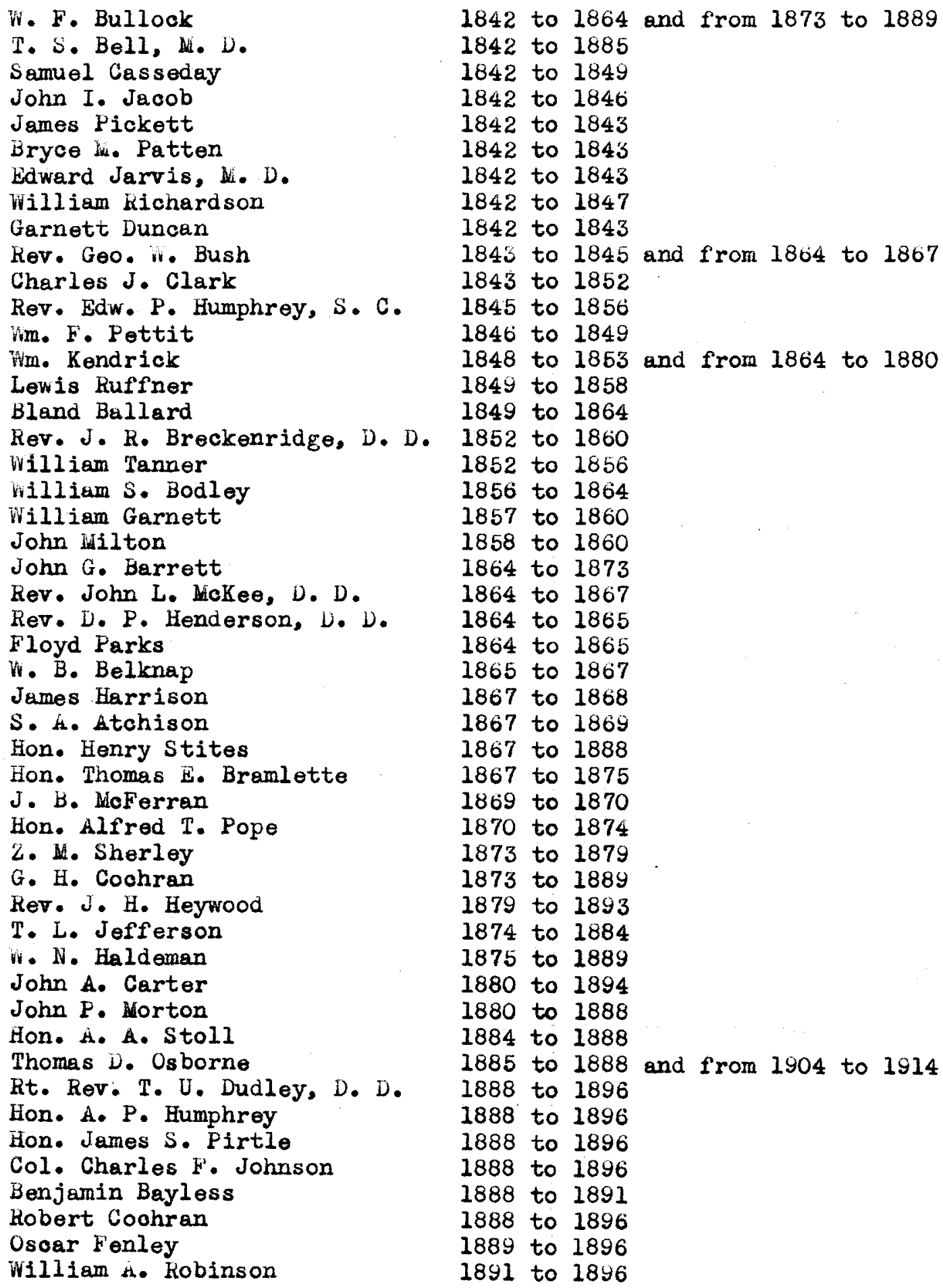


Col. Andrew Cowen Charles T. Ballard Dr. William Choatham James A. Leach Dr. L. S. Molurtry Kev. A. Moses, D. D. M. Muldoon Logan C. Murray Hon. A. E. Wilson Dr. James B. Steodman Gen'l Bennett H. Young Thomas L. Jefferson Walter Walker Henry Y. Offutt Hon. Henry S. Barker Dr. Frank C. Simpson Col. Zack Phelps Henry Kaufiman Daniel S. Mills Frank N. Hartwell D. W. Fairleigh Dr. S. Brozozowski D. $\mathbf{x}$. Murphy iw. Garnett Hunn Charles P. Weaver T. C. Timberlake John C. Cox iv. H. Bartholomew T. F. Satterwhite, Jr. w. S. Kaltenbacher Muir weissinger E. R. Atkisson

Pauline Eckenroth John Marshall Walter K. Belknap Wm. S. Speed Henry D. Orms by Richard R. Williams Stanley A. Berry Col. Henry O. Gray Robert H. Lucas, Sr. Dr. T. M. Howe Mrs. Ray G. Ratterman Mrs. W. G. Dearing Robert L. Hawes Edgar W. Busath Thomas C. James Mrs. W. Bayse Howell John F'. Adams Dan W. Lawler James H. Gold Lewis L. Dresoher Fred W. Finter C. W. Brickley
1896 to 1900 and from 1908 to 1912 1896 to 1900

1896 to 1900

1896 to 1900

1896 to 1900

1896 to 1902

1896 to 1900

1896 to 1900 and from 1908 to 1912

1896 to 1900

1900 to 1908 and from 1912 to 1914

1900 to 1908 and $f$ rom 1912 to 1919

1900 to 1908 and from 1912 to 1925

1900 to 1908

1900 to 1908

1900 to 1908

1900 to 1908

1900 to 1902

1902 to 1912

1908 to 1910

1908 to 1912

1908 to 1912

1908 to 1912

1910 to 1912

1910 to 1912

1912 to 1919

1912 to 1919

1912 to 1914

1912 to 1914

1912 to 1914

1914 to 1930

1919 to 1920

1919 to 1920

1919 to 1920

1920 to 1922

1920 to 1930

1920 to 1927

1922 to 1930

1925 to 1927

1927 to 1930

April 1930 to June 1930

April 1930 to June 1930

1930 to Maroh 1932

1930 to March 1932

1930 to March 1932

1930 to March 1932

1930 to March 1932

1932 to June 1933

1932 to June 1936

1932 to ....

1932 to April 1934

1932 to ....

1933 to April 1934

1934 to ....

1934 to June 1936 
THE OFFICE OF PRESIDENT HAS BEEN HELD BY:

Hon. Wm. F. Bullook

Dr. T. S. Bell

Hon. James S. Pirtle

Col. Andrew Cowen

Gen'l Bennett H. Young

Col. Andrew Cowan

Gen'l Bennett H. Young

T. L. Jefferson

H. D. Ormsby

Col. Henry O. Gray

$\mathrm{Dr}$. T. M. Howe

T. C. James

James H. Gold
1842 to 1864 and from 1885 to 1888

1864 to 1885

1888 to 1896

1896 to 1900

1900 to 1908

1908 to 1918

1912 to 1919

1919 to 1925

1925 to April 17, 1930

April 17, 1930 to June 30, 1930

1930 to March 1932

1932 to June 1933

1933 to $\ldots$.

THE OFFICE OF TREASURER HAS BEEN HELD AS FOLLONS:

Samuel Cassoday

William Richardson

John Milton

John G. Barrett

William S. Parker

Logan C. Murray

Thomas L. Jefferson

Logan C. Murray

Albert S. Rice

Frank M. Gettys

Williem R. Cobb

S. Albert Phillips
1842 to 1843

1843 to 1854

1854 to 1860

1860 to 1890

1890 to 1899

1899 to 1900

1900 to 1908

1908 to 1912

1912 to 1915

1915 to 1919

1919 to 1932

1932 to ....
THE OFFICE OF SUPERINTENDENT HAS BEEN HELD AS FOLLOWS:

Bryce M. Patten
B. B. Huntoon
Susan B. Merwin
C. B. Martin
Catherine Moriarty

1842 to 1871

1871 to 1912

1912 to 1923

1923 to 1930

1930 to .... 
NUMBER OF STUDENTS ENROLLED EACH YEAR IN KENTUCKY SCHOOL FOR THE BLIND

\begin{tabular}{|c|c|c|c|c|c|}
\hline YEAR & $\begin{array}{l}\text { NUMBER OF } \\
\text { WHITE PUPIIS }\end{array}$ & YEAR & $\begin{array}{l}\text { NUMBER OF } \\
\text { WHITE PUPILS } \\
\end{array}$ & $\begin{array}{l}\text { NUMBER } \\
\text { COLORED } \\
\end{array}$ & $\begin{array}{l}\text { OF } \\
\text { PUPIIS }\end{array}$ \\
\hline 1842 & $\ldots \ldots 10$ & 1886 & 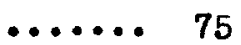 & $\bullet \ldots \ldots$ & \\
\hline 1843 & $\ldots \ldots \ldots 19$ & 1887 & $\ldots \ldots \ldots$ & $\ldots \ldots \ldots \ldots$ & \\
\hline 1844 & $\ldots \ldots \ldots 22$ & 1888 & $\ldots \ldots$ & $\ldots \ldots \ldots$ & \\
\hline 1845 & $\ldots \ldots \ldots 24$ & 1889 & $\ldots \ldots \ldots$ & $\ldots \ldots \ldots . \ldots 24$ & \\
\hline 1846 & $\ldots \ldots .31$ & 1890 & $\ldots \ldots 93$ & $\ldots \ldots \ldots 28$ & \\
\hline 1847 & $\ldots \ldots 31$ & 1891 & $\ldots \ldots 96$ & $\ldots \ldots \ldots 25$ & \\
\hline 1848 & $\ldots \ldots 38$ & 1892 & $\ldots \ldots 94$ & $\ldots \ldots \ldots 25$ & \\
\hline 1849 & $\ldots \ldots \ldots 38$ & 1893 & $\ldots \ldots 101$ & $\ldots \ldots \ldots \ldots 23$ & \\
\hline 1850 & $\ldots \ldots \ldots 43$ & 1894 & $\ldots \ldots 101$ & $\ldots \ldots \ldots 26$ & \\
\hline 1851 & $\ldots \ldots 35$ & 1895 & $\ldots \ldots 107$ & $\ldots \ldots \ldots \ldots$ & \\
\hline 1852 & $\ldots \ldots \ldots 41$ & 1896 & $\ldots \ldots 101$ & $\ldots \ldots \ldots 26$ & \\
\hline 1853 & $\ldots \ldots \ldots 38$ & 1897 & $\ldots \ldots 104$ & $\ldots \ldots \ldots 24$ & \\
\hline 1854 & $\ldots \ldots . .30$ & 1898 & $\ldots \ldots 112$ & $\ldots \ldots \ldots 24$ & \\
\hline 1855 & $\ldots \ldots . .38$ & 1899 & $\ldots \ldots 103$ & $\ldots \ldots \ldots 21$ & \\
\hline 1856 & $\ldots \ldots .50$ & 1900 & $\ldots \ldots 120$ & $\ldots \ldots 30$ & \\
\hline 1857 & $\ldots \ldots \ldots 75$ & 1901 & $\ldots \ldots 114$ & $\ldots \ldots \ldots 29$ & \\
\hline 1858 & $\ldots \ldots \ldots 56$ & 1902 & $\ldots \ldots 125$ & $\ldots \ldots \ldots 28$ & \\
\hline 1859 & $\ldots \ldots \ldots 51$ & 1903 & $\ldots \ldots 125$ & $\ldots \ldots \ldots 27$ & \\
\hline 1860 & $\ldots \ldots 50$ & 1904 & $\ldots \ldots 131$ & $\ldots \ldots \ldots 25$ & \\
\hline 1861 & $\ldots \ldots 44$ & 1905 & $\ldots \ldots 122$ & $\ldots \ldots \ldots 20$ & \\
\hline 1862 & $\ldots \ldots 35$ & 1906 & $\ldots \ldots 127$ & $\ldots \ldots \ldots 19$ & \\
\hline 1863 & $\ldots \ldots . .42$ & 1907 & $\ldots \ldots 134$ & $\ldots \ldots \ldots 26$ & \\
\hline 1864 & $\ldots \ldots 44$ & 1908 & $\ldots \ldots \ldots 128$ & $\ldots \ldots \ldots \ldots$ & \\
\hline 1865 & $\ldots \ldots .53$ & 1909 & $\ldots \ldots 123$ & $\ldots \ldots \ldots \ldots$ & \\
\hline 1866 & $\ldots \ldots 65$ & 1910 & $\ldots \ldots \ldots 112$ & $\ldots \ldots \ldots 26$ & \\
\hline 1867 & $\ldots \ldots \ldots 65$ & 1911 & $\ldots \ldots 114$ & $\ldots \ldots \ldots . . .23$ & \\
\hline 1868 & $\ldots \ldots .51$ & 1912 & $\ldots \ldots 116$ & $\ldots \ldots \ldots 23$ & \\
\hline 1869 & $\ldots \ldots \ldots 57$ & 1913 & $\ldots \ldots 115$ & $\ldots \ldots \ldots 28$ & \\
\hline 1870 & $\ldots \ldots \ldots 64$ & 1914 & $\ldots \ldots 118$ & $\ldots \ldots \ldots \ldots 27$ & \\
\hline 1871 & $\ldots \ldots .58$ & 1915 & $\ldots \ldots 121$ & $\ldots \ldots \ldots 24$ & \\
\hline 1872 & $\ldots \ldots \ldots 5$ & 1916 & $\ldots \ldots 131$ & $\ldots \ldots \ldots .28$ & \\
\hline 1873 & ..... 59 & 1917 & $\ldots 126$ & $\ldots \ldots \ldots \ldots 25$ & \\
\hline 1874 & $\ldots \ldots 74$ & 1918 & $\ldots \ldots 106$ & $\ldots \ldots \ldots \ldots 24$ & \\
\hline 1875 & $\ldots \ldots .84$ & 1919 & $\ldots \ldots 107$ & $\ldots \ldots \ldots 15$ & \\
\hline 1876 & $\ldots \ldots 95$ & 1920 & $\ldots \ldots 114$ & $\ldots \ldots \ldots 16$ & \\
\hline 1877 & $\ldots \ldots 85$ & 1921 & $\ldots \ldots 114$ & $\ldots \ldots \ldots 16$ & \\
\hline 1878 & .... 89 & 1922 & $\ldots \ldots 103$ & $\ldots \ldots \ldots \ldots 17$ & \\
\hline 1879 & $\ldots \ldots 85$ & 1923 & $\ldots . . .93$ & $\ldots \ldots \ldots \ldots 17$ & \\
\hline 1880 & $\ldots \ldots 78$ & 1924 & $\cdots \ldots \ldots$ & $\ldots \ldots \ldots 15$ & \\
\hline 1881 & $\ldots \ldots .81$ & 1925 & $\ldots \ldots 93$ & $\ldots \ldots \ldots 15$ & \\
\hline 1882 & $\ldots \ldots 77$ & 1926 & $\ldots \ldots 89$ & $\ldots \ldots \ldots 14$ & \\
\hline 1883 & $\ldots \ldots 78$ & 1927 & $\ldots \ldots .97$ & $\ldots \ldots \ldots \ldots 15$ & \\
\hline 1884 & $\ldots \ldots 81$ & 1928 & $\ldots \ldots 96$ & $\ldots \ldots \ldots 15$ & \\
\hline 1885 & $\cdots \ldots 77$ & 1929 & $\ldots \ldots 87$ & $\ldots \ldots \ldots 14$ & \\
\hline & & 1930 & $\ldots \ldots 78$ & $\ldots \ldots \ldots 18$ & \\
\hline
\end{tabular}




\section{BIBLIOGRAPHY}




\section{BIBLIOGRAPHY}

PRIMARY SOURCES :

Acts of Legislation Affecting the Amerioan Printing House for the Blind, Louisville, Ky•, Amerioan Printing Hous $\theta$ for the Blind, 1934.

Acts of the General Assembly of the Commonwealth of Kentucky, Frankfort, Ky, State Printer, 1842-1930.

Collins, G., Directory of Louisville For the Years 1843 and 1844, Louisville, Ky,. A. S. Tilden, Printer, 1843.

Deed Book, Numbers 61, 84, 92, 93, Louisville, Ky., Jefferson County Court House.

Kentuoky Doouments, "Fifth Annual Report of the Superintendent of Public Instruotion," Frankfort, Ky, State Printer, 1843.

Kentucky General Assembly, House, Journal, Frankfort, Ky, State Printer, 1842-1930.

Kentucky General Assembly. Senate, Journal, Frankf'ort, Ky., State Printer, 1842-1930.

Proceedings of the 24th Biennial Convention of the American Association of Institutions for the Blind, Colorado springs, Colorado, 1918.

Reports of the American Printing House for the Blind, Louisville, Ky., Amerioan Printing House for the BIind, 1883, 1919, 1920, 1941 .

Reports of the Kentuaky Institution for the Education of the Blind, Frankfort and Louisville, Ky•, State Printer, 1843-1930.

United States Statutes At Large, Washington, D. C., U. S. Government Printing Office, 1879, 1919, 1927, 1937.

University of Louisville Board of Trustees, Minute Books, 1846-1893. 
NEHSPAPERS :

Courier-Journal, Louisville, Kentucky

May 10, 1923

November 23, 1923

November 27, 1923

February 27, 1927

June 13, 1930

Frank Leslie's Illustrated Newspaper, Louisville, Ky, June 19, 1880.

Herald-Post, Louisville, Kentucky, Harch 6, 1929.

Louisville Daily Demoorat, Louisville, Ky., September 30, 1851.

Louisville Daily Journal, Louisville, Ky., September 30, 1851.

Louisville Herald, Louisville, Kentucky,

September 30, 1919

June 6,1923

November 22, 1924

Louisville Post, Louisville, Ky., May 7, 1923.

Louisville Times, Louisville, Kentucky, September 27, 1919

May 7, 1923

Nay 14, 1923

November 11, 1936

The Daily Courier, Louisville, Ky., September 30, 1851.

Tri-Weekly Kentucky Yoeman, Frankfort, Kentucky, Ootober 2, 1851. 
ENCYCLOPEDIAE:

Encyolopedia Britannica, Eleventh Edition, Vol. IV, New York, 1910 Sir Francis J. Campbell, "Blindness."

- - - - - - - - 1943 Edition, Vol. III, New York, 1943, Harry Best, "Blindness."

New International Encyclopedia, Vol. III, Dodd, Mead, and Co., New York, 1926, Mcha日 Anagnos and Dr. David G. Yates, "Bducation of the Blind."

The Catholic Encyclopedia, Vol. VII, Robert Appleton Co., New York, 1910, Joseph M. Stadelman, "Hauy."

INDEXES :

Check List of Kentucky Newspapers, The Filson Club, Louisville, Ky., Compiled by Ludie J. Kinkead, The Filson Club and Thomas Clark, University of Kentucky, 1935. Mineograph with later typewritten additions.

Hasse, Adelaide R., Index of Economic Material in Documents of the States of the United States, Carnegie Institution of Washington, 1910.

INTERV IEWS :

Mr. A. C. Ellis, Superintendent of the American Printing House for the Blind, Louisville, Kentucky.

Mr. and Mrs. Clifford B. Martin, former superintendent and teacher, Kentucky School for the Blind, Jeffersontown, Kentucky.

Mir. Harold Reagan, Concession Stand, Jefferson County Court House, Louisville, Kentucky. 
SECONDAKY SOURCES :

Battey, F. A., \& Co., Kentucky, A History of the State, Sixth Edition, Louisville, Kentucky, 1887.

Best, Harry, Blindness and the Blind in the United States, Maomillan Company, New York, 1934.

Clift, Glenn G., Governors of Kentucky, Hobson Press, Cynthiana, Kentucky, 1942.

Dexter, Edwin Grant, A History of Bducation in the United States, Macmillan Company, Now York, 1904.

Eby, Frederick, and Arrowood, Charles Flinn, The Development of Modern Education, Prentice-fall, Ino., New York, 1934.

French, Richard Slaton, From Homer to Helen Keller; a Social and Educational Study of the Blind, hmerican Foundation For the Blind, New York, 1932.

History of the Ohio Falls Cities and Their Counties, with Biographical Sketches, 2 volumes, Cleveland, L. A. Williams and Company, 1881 .

Johnston, J. Stoddard, A Memorial History of Louisville, 2 volumes, American Blographical Publishing Company, Chicago and New York, 1896.

Kelly, H. A., and Burrage, W. L., Dictionary of American Medical Biography, D. Appleton and Company, New York, 1928.

Work Projeots Administration of the State of Kentucky, Louisville, A Guide to the Falls Cities, 1940. 